Portland State University

PDXScholar

\title{
Effects of Evaporative Cooling in the Thermal Performance of Green Roofs
}

Giorgina Beatriz Castillo Garcia

Portland State University

Follow this and additional works at: https://pdxscholar.library.pdx.edu/open_access_etds Let us know how access to this document benefits you.

\section{Recommended Citation}

Castillo Garcia, Giorgina Beatriz, "Effects of Evaporative Cooling in the Thermal Performance of Green Roofs" (2011). Dissertations and Theses. Paper 181.

https://doi.org/10.15760/etd.181

This Thesis is brought to you for free and open access. It has been accepted for inclusion in Dissertations and Theses by an authorized administrator of PDXScholar. Please contact us if we can make this document more accessible: pdxscholar@pdx.edu. 


\title{
Effects of Evaporative Cooling
}

in the Thermal Performance of Green Roofs

by

Giorgina Beatriz Castillo Garcia

A thesis submitted in partial fulfillment of the requirements for the degree of

\author{
Master of Science \\ in \\ Mechanical Engineering
}

Thesis Committee:

Graig Spolek, Chair

David Sailor

Sergio Palleroni

Portland State University

(C)2011 


\begin{abstract}
Green roofs have become an important urban mitigation technology due to their ability to address multiple environmental issues. One of the most common benefits attributed to green roofs is the reduction in heating and cooling loads in buildings by dissipating heat through evaporation. This study focuses on evaluating the effect that evaporative cooling has on the thermal performance of green roofs. Sponge and floral foam were used as porous media for their ability to retain water inside its body, transport it to the surface, evaporate it at a constant rate and for their different pore sizes. Test trays containing sponge or floral foam saturated with water were tested in a low speed wind tunnel equipped to measure weight, temperature and heat flux. Two types of experiments were conducted: one with evaporation at the surface, and the other with evaporation blocked by an impervious layer. The testing conditions for all tests were kept constant except for the ability of evaporation to happen. Evaporation rate for floral foam was $0.14 \mathrm{~kg} / \mathrm{m}^{2} \mathrm{hr}$ and $0.29 \mathrm{~kg} / \mathrm{m}^{2} \mathrm{hr}$ for sponge. Results of tests with evaporation show a decrease of $45-49 \%$ in heat conducted through the roof when compared to the tests without evaporation. For optimal thermal performance of green roofs, a material that enhances water transport and thus evaporation at the surface is necessary with large pores and low field capacity. Surface temperatures on test with evaporation were found to be between $3-7^{\circ} \mathrm{C}$ lower than those
\end{abstract}


without evaporation. Applying a 2 sample t-test to the data, the relationship between heat flux and evaporation was found to be statistically significant. 


\section{ACKNOWLEDGEMENTS}

I would like to thank Dr. Graig Spolek, my thesis advisor, for his patience, guidance and ongoing support. Without his kindness and expertise this study would not have been possible. I also thank Dr. David Sailor, Dr. Sergio Palleroni, Dr. Huafen Hu, Dr. Derek Tretheway, and Dr. Mark Weislogel.

I want to express my gratitude to my friends in the GBRL and surface tension labs: Debbie Beck, Eduardo Guerrero, Ziyang Liu, Bryce Cox, Alex Baker, and Donald Bell for their ongoing moral support and assistance throughout my time in the lab.

I am grateful for the support, inspiration, encouragement and patience of my sisters and nieces; Karina, Carolina, Andrea and Camila; and to the family I have found in Portland: Jesse, Travis, Cherie, Tom and Laura.

Finally, and most importantly, I want to thank my parents: Nerio and Nancy, for being my pillars. Without their understanding, absolute confidence in my abilities and endless patience this thesis would never have existed. 


\section{TABLE OF CONTENTS}

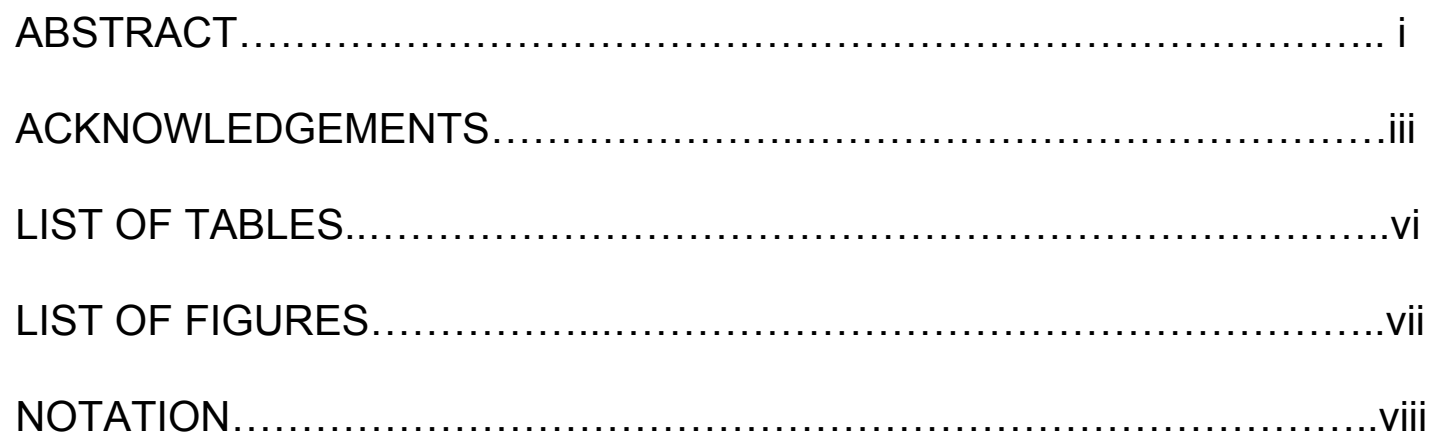

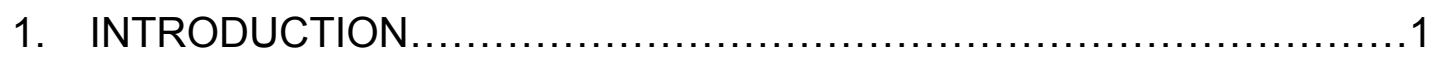

1.1. Green Roofs......................................................

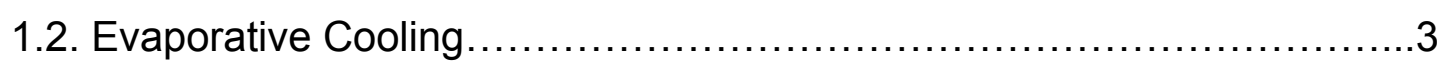

2. HEAT TRANSFER IN GREEN ROOFS $\ldots \ldots \ldots \ldots \ldots \ldots \ldots \ldots \ldots \ldots \ldots \ldots \ldots$

2.1. Heat Transfer Mechanism in Green Roofs.............................. 10

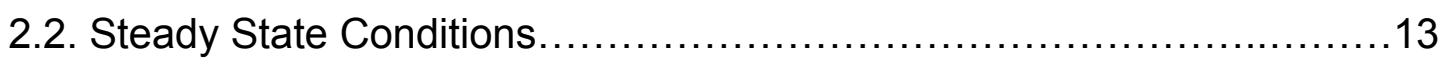

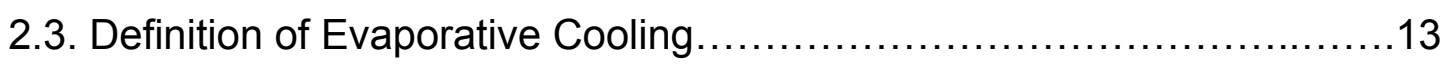

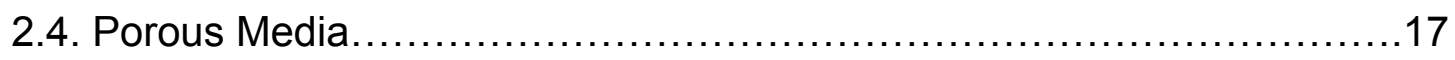

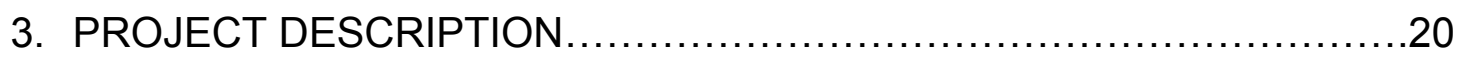

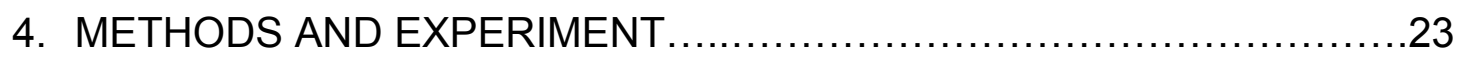

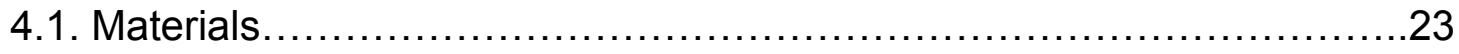

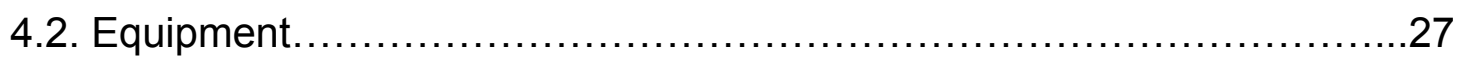

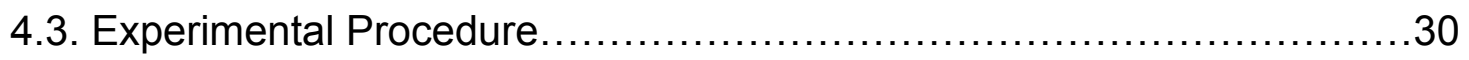


5. RESULTS AND DISCUSSION..........................................

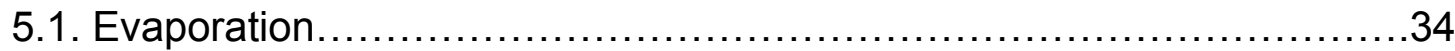

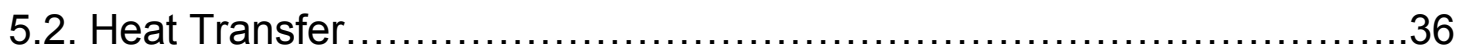

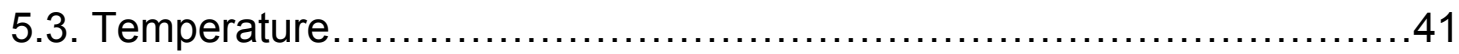

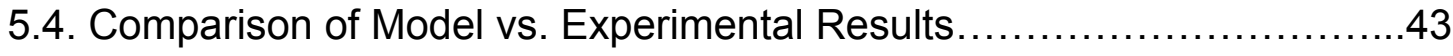

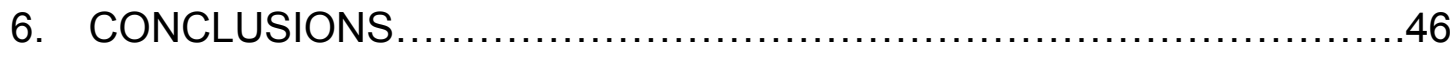

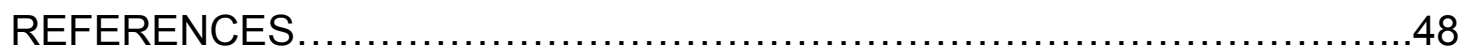

APPENDIX A: Raw Test Results...........................................53

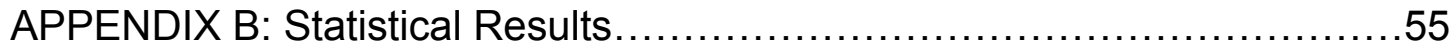




\section{LIST OF TABLES}

Table 1. Evaporation rates for Waphen and Nagano $(2009) \ldots \ldots \ldots \ldots \ldots . . . .8$

Table 2. Evaporation rates for sponge and floral foam...................35

Table 3. Average heat transferred through the material...................37

Table 4. Average surface temperatures of sponge and floral foam.......42

Table 5. Predicted and experimental evaporation rates results...........44 


\section{LIST OF FIGURES}

Figure 1. Energy balance diagram for a green roof......................10

Figure 2. Energy balance of a green roof slab with blocked evaporation.....................................................

Figure 3. Image of the sponge's pores under a microscope...............24

Figure 4. Image of the floral foam's pores under a microscope............25

Figure 5. Cross sectional view of the testing unit (GERTY) ..............28

Figure 6. Locations of thermocouples and heat sensors in the testing

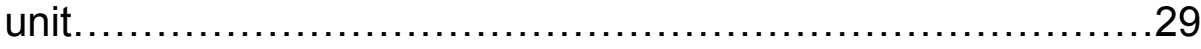

Figure 7. Image of sponge filled tray in the testing unit...................32

Figure 8. Image of floral foam filled tray in the testing unit................33

Figure 9. Weight change of the tested porous materials...................34

Figure 10. An individual value plot of the data collected in the experiments with and without evaporation of water at the surface using floral foam..............................................

Figure 11. An individual value plot of the data collected in the experiments with and without evaporation of water at the surface using sponge

Figure 12. Surface temperature over time for the experiments with and without evaporative cooling using floral foam and sponge.......42 


\section{NOTATION}

$\begin{array}{ll}\mathrm{q}_{\text {conv }} & \text { Convective heat flux } \\ \mathrm{q}_{\text {cond }} & \text { Conductive heat flux } \\ \mathrm{q}_{\mathrm{evap}} & \text { Heat flux due to evaporation } \\ \mathrm{k} & \text { Thermal conductivity of the material } \\ \mathrm{h} & \text { Effective convective heat transfer coefficient } \\ \mathrm{h}_{\mathrm{fg}} & \text { Latent heat of vaporization at the surface } \\ \mathrm{h}_{\mathrm{c}} & \text { Height of capillary rise } \\ \mathrm{t} & \text { Time } \\ \mathrm{r} & \text { Capillary radius } \\ \mathrm{g} & \text { Gravitational acceleration } \\ \dot{m} & \text { Rate of evaporation } \\ \mathrm{A} & \text { Area } \\ \mathrm{V} & \text { Air velocity } \\ \mathrm{T}_{\infty} & \text { Ambient air temperature } \\ \mathrm{T}_{\mathrm{s}} & \text { Surface temperature } \\ \mathrm{T}_{\mathrm{C}} & \text { Temperature in the cold section } \\ \mathrm{L} & \text { Thickness of the material } \\ \mathrm{C} & \text { Mass transfer term } \\ \Phi_{\infty} & \text { Relative humidity } \\ \beta & \text { Bowen ratio } \\ \Delta w & \text { Change in weight } \\ \gamma & \text { Surface tension } \\ \rho_{w} & \text { Water density } \\ \alpha & \text { Wetting angle } \\ & \end{array}$




\section{INTRODUCTION}

\subsection{Green Roofs}

Urbanization has been the dominant demographic trend in the United States for over a century. The rapid development of cities has led to a great increase in buildings, industries and people. According to the United Nations, projections suggest that the percentage of world population living in urban areas will grow from $50 \%$ currently to $70 \%$ by 2050 (United Nations, 2008). The more populated a city is, the more environmental challenges it faces. One negative environmental impact that this causes is the increase in energy consumption for cooling and heating in buildings. According to the Lawrence Livermore National Laboratory (2007), it was estimated that in the United States the total energy consumed by residential and commercial buildings was 19.9 Quads in 2007, which corresponds to the third largest energy user sector in the country. In a typical commercial or residential building, the top sources of energy consumption are space cooling and heating, followed by water heating, lighting, electronics, and ventilations.

Green roofs, or eco-roofs, have become increasingly popular as an important urban mitigation technology. A green roof refers to a conventional roof on a building that is partially or completely covered with vegetation. A typical system consists of a series of layers including a waterproof and root- 
proof membrane, a drainage layer for excess water, a filter fabric, soil and plants (Lazzarin et al, 2005; Bass and Baskaran, 2003; Sailor 2008; Kosareo and Ries, 2006).

The popularity of green roofs has increased in recent years due to their versatility with regard to addressing multiple environmental issues. Some of the more common benefits attributed to green roofs, which are addressed in this study, include the potential to mitigate urban heat island effect (Santamouris et al., 2001; Wanphen et al., 2007) and the ability to reduce energy usage for heating and cooling by dissipating heat (Feng et al., 2009; Saiz et al., 2006; Gaffin et al., 2005). Other environmental benefits documented in green roof literature are their ability to store rainwater and to reduce runoff volume to the city sewage system (Moran et al., 2005; Jarrett et al., 2006), the ability to provide a habitat for local species of insects and birds (Coffaman and Davis, 2005; Brenneisen, 2006; Kadas, 2006), and the ability to remove air pollution (Yang et ak., 2008; Beckett et al., 1998; Hill, 1971).

The thermal benefits of green roofs are derived from different aspects. Green roofs minimize solar gain through vegetation shading the roof and by the plants absorbing or reflecting much of the incoming solar radiation before it strikes the building. Plants can also act as insulation by reducing convective heat flow and thus reducing heat flux through the roof into the space below. The soil can act as a thermal resistance and as a heat sink. There is also the 
effect of evapotranspiration from the vegetation and soil; evapotranspiration is the combined effect of evaporation from the soil and plants and transpiration from the plants. It is the cooling effect of the evaporation of water from the soil surface that motivates the present work.

\subsection{Evaporative Cooling}

Past research has studied the energy balance of green roofs and concluded that in some situations the dominant way for green roofs to dissipate the absorbed heat is by evapotranspiration (Theodisio, 2003; Lazzarin et al., 2005; Onmura et al., 2001).

The thermal performance of two green roofs installed in buildings in Portland, Oregon, which were exposed wet and mild climate conditions, was investigated by Spolek (2008). A green roof installed on the roof of a student housing building at Portland State University and a portion of rock ballast roof to be used for reference exposed to the same weather conditions were equipped with an array of temperature sensors to monitor the transmission of heat through the roof. During summer conditions, the green roof reduced the variations in surface temperature when compared to the rock ballast surface. Data from the winter and summer of 2006 show that there was a $13 \%$ reduction in heat flux during winter conditions, and a $72 \%$ reduction in heat flux during summer. Although it was demonstrated that the green roof was 
effective in reducing heat transferred through the roof of the building, it was not determined which factor (better insulation for dry soil, shading by the plants or evapotranspiration) contributed the most to the results.

Feng, Meng and Zhang (2010) presented a mathematical model to analyze the energy balance of extensive green roofs in order to better understand its heat transfer mechanisms. The data fed into the mathematical model was measured and recorded during the summer time. An experimental green roof slab was installed in a building in China and equipped with instrumentation to measure incident solar radiation, ambient air temperature, dew point of ambient air, wind speed above the canopy, soil water content, leaf and soil temperatures, and heat transferred into the room beneath. The authors concluded that in typical summer day, when soil was moist, $58.4 \%$ of the heat dissipated by the green roof was by evapotranspiration of the plantssoil system, $30.9 \%$ by the net long-wave radiative exchange between the canopy and the atmosphere, $9.5 \%$ by the net photosynthesis of plants, and $1.2 \%$ was stored by the plants and soil or transferred into the room below.

In warm climates, evapotranspiration can create 'oases' that are 2-8C cooler than their surroundings (Oke, 1987; Taha et al., 1989 and 1991). More recently, Gaffin and colleagues (2006) simulated green roof temperature data by including a latent heat loss parameter into an energy balance model for non-green roofs. The modeling effort was to quantify the ratio of sensible to 
latent heat flow in order to investigate which of the two contributes more heat loss from a green roof. The Bowen ratio $(\beta)$, which is a ratio of sensible to latent heat, was used. The model calculated the surface temperature of the roof using data on solar radiation, wind speed, relative humidity, roof layer thermal conductivity and air bottom and top layer temperatures available from Pennsylvania State University's green roof experimental stations. $\beta$ was adjusted to best fit the model to the experiment. The research found a range for $\beta$ of $0.12-0.35$, indicating that latent losses were a factor of 3-8 times larger than sensible heat losses. However, this paper fails to be conclusive in determining the effect that latent heat losses have on green roofs. The authors used data from an experimental green roof installed in the roof of a building, which had both transient heat and mass transfer behavior due to constant changes in the outdoor conditions. They assumed that the heat storage component in their model was small and that the Bowen ratio would remain constant. While the time constant for temperature fluctuations in a green roof may be of comparable order of magnitude to diurnal temperature swings, the time constant for mass transfer is about two orders of magnitude greater than for heat transfer. Assuming a constant $\beta$, then, is a questionable assumption for the use in prediction of rooftop temperature.

In Japan, Onmura et al (2001) investigated the effect of evaporative 
cooling on a roof lawn garden utilizing a lawn fabric layer instead of soil. The study was divided into two parts. Part one consisted of a field experiment carried out in a three story concrete building and was intended to show a reduction of heat into the room beneath. The green roof layers consisted of lawn, a planting layer (non-woven fabric), a drainage layer and a root intercepting layer. The experiment was carried out under hot and humid weather conditions. Results from this part of the study showed that the temperature of the concrete slab with green roof was $30^{\circ} \mathrm{C}$ lower under clear skies and $10^{\circ} \mathrm{C}$ lower under cloudy skies compared to the temperature of the concrete slab without green roof. Transient thermal calculations using the data collected showed that on a clear day, the total heat coming into the building with the green roof layer above the concrete roof, when compared to a concrete layer without green roof, was $2.17 \mathrm{MJ} / \mathrm{m}^{2}$ per day as compared to $4.74 \mathrm{MJ} / \mathrm{m}^{2}$ per day. On a cloudy day, heat transfer results with and without green roof layer are $1.08 \mathrm{MJ} . \mathrm{m}^{2}$ and $3.12 \mathrm{MJ} / \mathrm{m}^{2}$ respectively. The total heat flux coming into the room below was reduced by $50 \%$ irrespective of whether it was a cloudy or sunny day.

The second part of the study was carried out in a wind tunnel under controlled conditions to better understand the heat and moisture transport in the green roof. The use of a wind tunnel allowed for the simulation of different weather conditions at steady state. Four scenarios were carried out and 
measured: without solar radiation and without water supply; without solar radiation but with water supply; with solar radiation but without water supply; and with solar radiation and water supply. From this part of the study, it was concluded that the temperature distribution of the lawn is influenced not only by the heat flow but also by the moisture content and the water (vapor and liquid) diffused through the green roof.

Tang and Jiang (2009) compared the thermal performance between a green roof and a bare roof during a summer session in Shanghai. The green roof consisted of 4 inches of soil using sedum plants, while the bare roof was a reinforced concrete hollow slab. Results showed that the green roof's surface temperature was $4^{\circ} \mathrm{C}$ cooler than that of the bare roof. Heat flux incoming into the room below was reduced by $73 \%$ resulting in an electric power consumption reduction of $16 \%$. The authors calculated the thermal resistance of the green roof to be $5.68 \mathrm{ft}^{2} \mathrm{hr}$ F/BTU.

Other researchers have studied the passive cooling potential of materials other than plants to avoid the expensive installation cost and maintenance of green roofs. One of the advantages of this approach is that researchers are able to choose materials with physical and thermal properties that enhance the evaporative cooling effect.

Wanphen and Nagano (2009) investigated the use of alternative porous materials to moderate roof surface temperature by evaporative cooling effect. 
The experiments were carried out in a wind tunnel with controlled air temperature and relative humidity under stable conditions. The evaporation rates of the materials were calculated and the effect of evaporation on surface temperature was evaluated. Silica sand, pebbles, volcanic ash and siliceous shale were tested. The data in Table 1 shows that pore size has an insignificant effect on evaporation rate of the materials. However, comparison of the surface temperature of the materials tested and mortar concrete showed that evaporation from the surface of porous materials led to surface temperature reductions.

Table 1. Evaporation rates for layers of saturated porous materials (from Wanphen and Nagano, 2009)

\begin{tabular}{ccccccc}
\hline \multirow{2}{*}{ Materials } & \multicolumn{2}{c}{ Volcanic Ash } & \multicolumn{2}{c}{ Siliceous Shale } & Silica Sand & Pebbles \\
\cline { 2 - 5 } & Dia $<4 \mathrm{~mm}$ & Dia $>5 \mathrm{~mm}$ & Dia $<4 \mathrm{~mm}$ & Dia $>10 \mathrm{~mm}$ & & \\
\hline $\begin{array}{l}\text { Evaporation Rate } \\
\left(\mathrm{kg} \text { water } / \mathrm{m}^{2} \mathrm{~h}\right)\end{array}$ & 0.22 & 0.21 & 0.18 & 0.17 & 0.19 & 0.13 \\
\hline
\end{tabular}

Although green roofs haven been shown to have a positive effect in reducing the heat flux transferred into buildings during summer time conditions, studies show that they have a negligible effect in winter conditions. A study by Lazzarin and colleagues (2005) made a numerical model using building simulation software (TRNSYS) to evaluate the thermal performance of green roofs under different weather conditions. The data used in the model 
was gathered from an experimental green roof installed on the roof of a building in Italy. The experiments were carried out under summer and winter conditions. The authors concluded that the role of latent heat flux due to evapotranspiration is very important in the green roof's potential to reducing energy consumption in buildings. During summer with the soil in almost dry conditions, the green roof attenuated the heat gain entering the room below about $60 \%$ with respect to a traditional roof system. This was due to higher solar reflection and absorption of the planted roof, since the evapotranspiration was very limited. However when the soil was saturated with water and evapotranspiration was maximized, the authors observed an outgoing flux indicating that the wet green roof performed as a passive cooler. From the results of the experiments done during the winter conditions, the authors found that the green roof actually had a higher heat loss than the conventional roof.

Although the authors observed the cooling effect that evaporative cooling has on green roofs, the study is not conclusive since it was not factored into the model that the thermal conductivity of the soil changes with moisture. Sailor and colleagues (2008) measured the thermal conductivity of soil samples over a range of moisture states. They found that the thermal conductivity of soil increases with soil moisture. 


\section{HEAT TRANSFER IN GREEN ROOFS}

In order to learn how a green roof can affect the energy needs of a building, it is important to consider how it behaves as a thermal barrier between indoors and outdoors.

\subsection{Heat Transfer Mechanism in Green Roofs}

Consider a green roof represented by a bed of wet soil, with or without plants, with a steady stream of air blowing over the surface. During summer conditions, the air is warmer and its relative humidity lower than the green roof surface. The energy balance for the green roof surface can be described as the energy that flows in and out from the surface of the green roof, involving radiation, conduction, convection and evaporation (Figure 1).

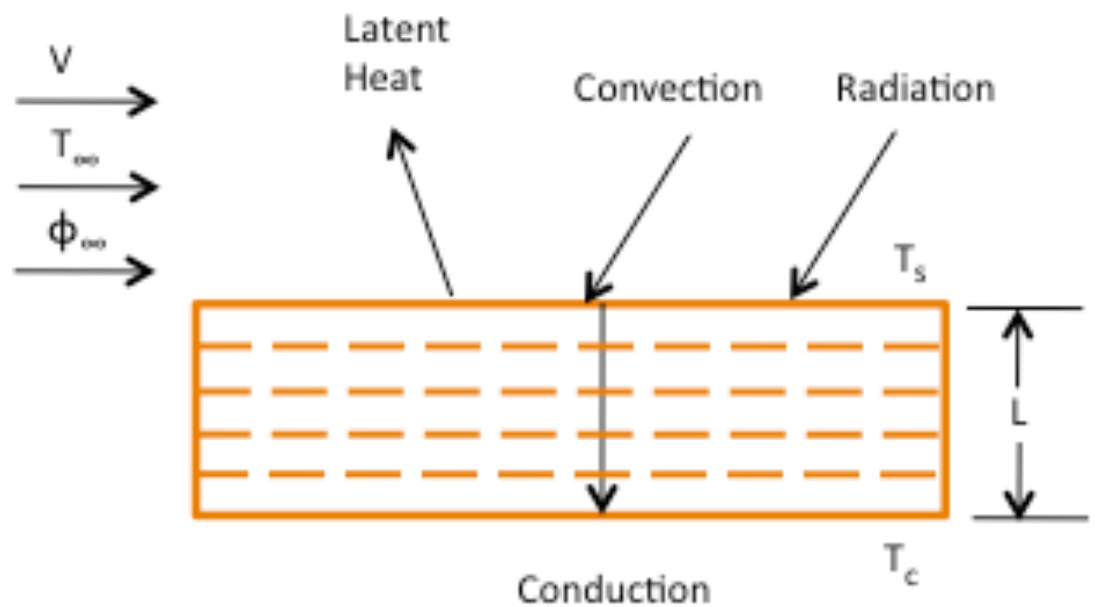

Figure 1: Energy balance diagram for a green roof 
Radiation occurs in the form of solar energy, some of which is reflected at varying rates, long-wave radiation exchange, radiation between leaves, radiation between leaves and soil, and radiation from soil and plants to the sky at night. This combination of radiation mechanisms can be accounted for by assuming a total convective heat flux proportional to the temperature difference between ambient and surface, since convection, or sensible heat, is gained due to wind blowing warm air across the cooler roof's surface.

\section{Equation 1}

$$
q c o n v=h\left(T \infty-T_{s}\right)
$$

Where: $\quad \mathrm{q}_{\mathrm{conv}}=$ rate of convection heat transfer, in $\mathrm{W} / \mathrm{m}^{2}$.

$$
\begin{aligned}
& \mathrm{h}=\text { effective convective heat transfer coefficient, including } \\
& \text { convection and radiation heat transfer, in } \mathrm{W} / \mathrm{m}^{2} \mathrm{~K} \text {. } \\
& \mathrm{T}_{\infty}=\text { ambient air temperature, in }{ }^{\circ} \mathrm{C} \\
& \mathrm{T}_{\mathrm{s}}=\text { surface temperature, in }{ }^{\circ} \mathrm{C}
\end{aligned}
$$

Conduction is the transfer of heat through a solid medium, in this case through the materials forming the roof.

\section{Equation 2}

$$
q c o n d=\frac{k\left(T_{s}-T_{c}\right)}{L}
$$

Where: $\quad \mathrm{q}_{\mathrm{cond}}=$ heat transfer through the material in the direction normal to the surface, from hot to cold, in $\mathrm{W} / \mathrm{m}^{2}$ 


$$
\begin{aligned}
& k=\text { thermal conductivity of the material, in } \mathrm{W} / \mathrm{m} \mathrm{K} \\
& T_{S}=\text { Surface temperature in } C \\
& T_{C}=\text { Cold temperature at the bottom of the green roof, in } C \\
& L=\text { thickness of the material, in } m
\end{aligned}
$$

Latent heat of evaporation is lost through the water vapor that leaves the green roof. It represents the thermal energy gained by water molecules that have undergone a phase transition from the liquid to the vapor phase. Since some of the convected heat is absorbed by evaporation, there is less heat conduction through the soil bed. Evaporation rate, the quantity of water evaporated per unit time, and latent heat can be estimated by:

\section{Equation 3}

$$
\text { qevap }=\dot{m} h f g
$$

Where: $\quad q_{\text {evap }}=$ heat absorbed through evaporation of water, in $\mathrm{W} / \mathrm{m}^{2}$

$$
\begin{aligned}
& \dot{m}=\text { rate of evaporation, in } \mathrm{kg} / \mathrm{m}^{2} \mathrm{~h} \\
& h f g=\text { latent heat of vaporization at the surface, in } \mathrm{kJ} / \mathrm{kg}
\end{aligned}
$$

\section{Equation 4}

$$
\dot{m}=\frac{\Delta w}{A \Delta t}
$$

Where: $\quad \dot{m}=$ rate of evaporation, in $\mathrm{kg} / \mathrm{m}^{2} \mathrm{~h}$

$$
\Delta \mathrm{w}=\text { change in weight, } \mathrm{kg}
$$

$$
A=\text { area, } m^{2}
$$




$$
\Delta t=\text { change of time, } h
$$

\subsection{Steady State Conditions}

A system is in thermal steady state when a set of conditions exhibit only negligible changes over a long period of time. In a roof or wall that separates two fluids with different temperatures, steady state conditions require that each temperature in the system, and the rate of heat flow through the wall or roof, does not change over time.

Considering the example of the green roof slab in Figure 1 at steady state, the heat fluxes are related by:

\section{Equation 5}

$$
\text { qcond }=\text { qconv }- \text { qevap }
$$

Substituting equations (1), (2) and (3) in equation (5), the steady state energy balance of the green roof becomes:

\section{Equation 6}

$$
\frac{k\left(T_{s}-T_{c}\right)}{L}=h\left(T_{\infty}-T_{s}\right)-\dot{m} h f g
$$

\subsection{Definition of Evaporative Cooling}

Evaporative cooling is a physical phenomenon in which heat is removed from a system by the evaporation of a liquid resulting in a cooling effect. Evaporation occurs when the molecules in the liquid near the surface 
experience collisions that increase their energy needed to overcome the liquidphase intermolecular forces. The energy needed to sustain the evaporation must come from the convective heat acting on the surface of the slab, which requires a reduction in the surface temperature to facilitate the necessary convection.

In order to better illustrate this phenomenon, it would be helpful to understand a simpler case first: a green roof slab with zero evaporation. Consider a green roof slab where evaporation of the surface water is blocked by an impermeable layer, which would impede mass transfer to occur while allowing convective and conductive heat transfer to continue. The energy balance of this system is presented in Figure 2.

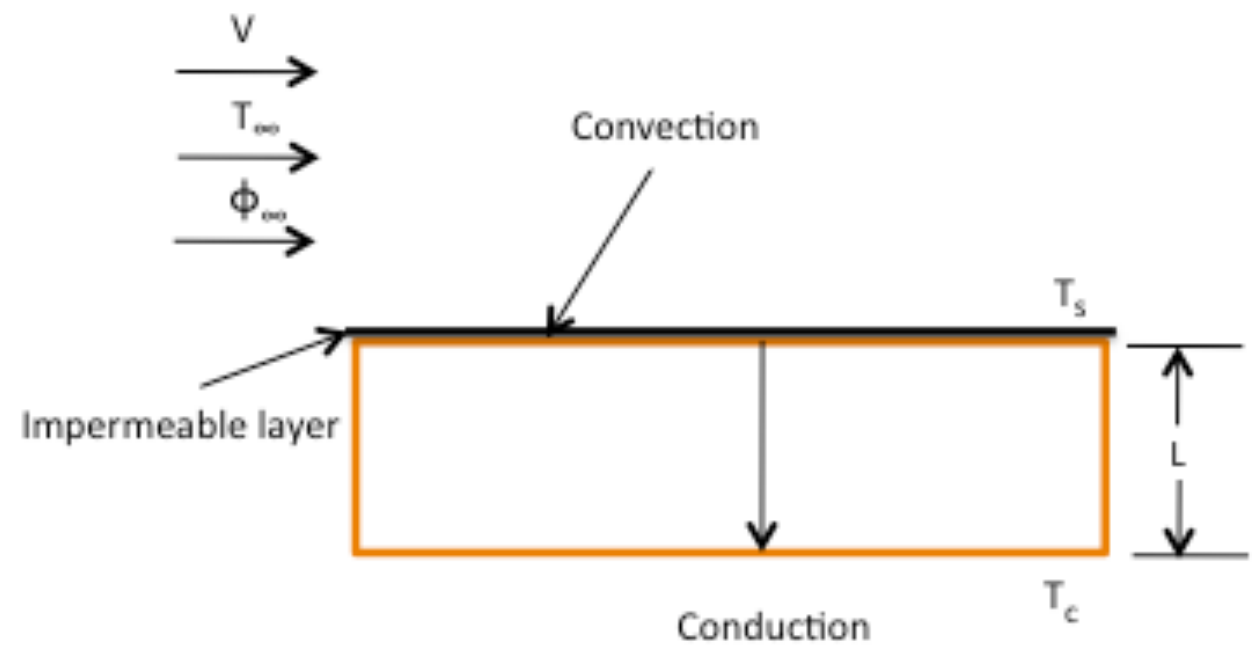

Figure 2. Energy balance of a green roof slab with blocked evaporation 
Assuming the system is in steady state condition, when evaporation is zero, the energy balance of the system is reduced to the conductive and convective components of the model. Then, equation (5) is simplified to heat transferred through the green roof slab is equal to the convected heat gained through the slab's surface.

Solving equation (6) for the surface temperature $\left(T_{s}\right)$ with zero evaporation:

\section{Equation 7:}

$$
T_{s}=\frac{k T_{c}+h L T_{\infty}}{h L+k}
$$

The surface temperature $\left(T_{s}\right)$ is a function of the effective heat transfer coefficient $(\mathrm{h})$. If the thickness of the slab, the thermal conductivity of the soil and the temperatures of the system are kept constant, the surface temperature will vary only with the effective heat transfer coefficient. Examining the limits of this behavior, when the heat transfer coefficient is zero, the system is considered adiabatic: there is no heat transfer in the system and the surface temperature is equal to the cold temperature of the system $\left(T_{c}\right)$, implying no temperature gradient.

In the case where the heat transfer coefficient is:

$$
h=\frac{k}{L}
$$


Then, the system is transferring heat only through conduction and the resulting surface temperature is an average of the ambient and cold temperatures of the system.

When the heat transfer coefficient $(h)$ is immensely large and approaches infinity, then the convective resistance is negligible and the surface temperature would approach the ambient air temperature $\left(T_{\infty}\right)$.

This relationship for surface temperature $\left(T_{s}\right)$ holds when there is no mass transfer in the green roof system. However, when there is evaporation occurring at the surface of the green roof, the solution must include the mass transfer term $\left(\dot{m} h_{f z}\right)$. This case might occur for a layer of highly porous soil with high capillary pressure. Soil is composed of particles of broken rock packed loosely, forming a soil structure filled with pore spaces. By using a porous soil with high capillarity in the green roof, it is possible to use their moisture absorption and evaporative qualities to maintain a constant supply of water at the surface of the slab as water is being evaporated, thus resulting in a constant evaporation rate in the system. Moreover, if the latent heat of vaporization at the surface $\left(\mathrm{h}_{\mathrm{fg}}\right)$ is also constant, the mass transfer term $\left(\dot{m} h_{f z}\right)$ in the energy balance equation will be a constant term, ( $\left.C^{\prime}\right)$. Carrying this through the derivation, the effect on the surface temperature is:

\section{Equation 8}




$$
T_{s}=\frac{k T_{c}+h L T_{\infty}-C^{\prime}}{h L+k}
$$

Since there is evaporation occurring at the surface, the mass transfer term is greater than zero and is estimated by:

\section{Equation 9}

$$
C^{\prime}=\dot{m} h_{f s} L / k
$$

Comparing equations (8) and (9), it can be seen that $\left(T_{s}\right)$ reaches its maximum value when there is no evaporation in the system. But when evaporation is not zero, and as the evaporation rate $(\dot{m})$ increases, the surface temperature $\left(T_{s}\right)$ will decrease. This is consistent with physical behavior because evaporation will never increase the ambient air temperature but it may cause it to decrease.

\subsection{Porous Media}

For evaporation to be sustained, it is essential that water be continuously supplied to the surface through the interior body of the soil. This will depend on the water content in the soil as well on its water transport properties, which together will determine the maximum rate at which water can be transmitted to the evaporation site.

If the top layer of the soil is initially wet, the process of evaporation will reduce soil wetness and increase surface tension at the surface. This, in turn, 
will cause soil moisture to be drawn upward from the layers below, provided they are sufficiently moist.

According to Hillel (Hillel, D., 2004), if a shallow groundwater table is present within the soil and close to the surface, a continual flow may take place from the saturated zone beneath through the unsaturated soil to the surface. If this flow is more or less steady, continued evaporation can occur without materially changing the soil moisture content.

The rise of water in the soil through an interior bundle of narrow tubes from the free-water surface is termed capillary rise. The equation relating the height of the capillary rise to the radii of the pores is:

\section{Equation 10}

$$
h_{c}=\frac{(2 \gamma \cos \alpha)}{r \rho_{w} g}
$$

Where: $\quad h_{c}=$ height of capillary rise, $\mathrm{mm}$

$$
\begin{aligned}
& \gamma=\text { surface tension, } \mathrm{N} / \mathrm{m} \\
& \mathrm{r}=\text { capillary radius, } \mathrm{mm} \\
& \rho_{\mathrm{w}}=\text { water density, } \mathrm{kg} / \mathrm{m}^{3} \\
& \mathrm{~g}=\text { gravitational acceleration, } \mathrm{m} / \mathrm{s}^{2} \\
& \alpha=\text { wetting angle }
\end{aligned}
$$


This equation predicts that water will rise higher in a media with narrow pores. However, soil pores are not individual capillary tubes of uniform or constant radius, and thus the height of capillary rise will vary in different pores.

In general, when a water table is present, soil water does not attain equilibrium, since the soil surface is subject to solar radiation and the evaporative demand of the ambient atmosphere. However, if the soil and external conditions were constant, then in time, a steady-state flow situation can develop from the water table to the atmosphere via the soil. The steady rate of capillary rise and evaporation depends on the depth of the water table and on the suction at the soil surface. This suction is dictated largely by external conditions: the greater the atmospheric evaporativity, the greater the suction at the soil surface on which the atmosphere is acting. However, increasing the suction at the soil surface can increase the flux through the soil only up to an asymptotic maximal rate, which depends on the depth of the water table. Even the driest and most evaporative atmosphere cannot steadily extract water from the surface any faster than the soil profile can transport water to the surface. The maximal transmitting ability of the profile depends on the hydraulic conductivity of the soil in relation to the suction. 


\section{PROJECT DESCRIPTION}

The studies addressed in Chapter 1 have shown the thermal benefits of green roofs. Green roofs have been demonstrated to reduce the surface temperature of the roof, reduce the heat flux into the roof and reduce the energy consumption of buildings. Many researchers agree that the dominant mechanism for this reduction is evapotranspiration. Some studies have attempted to identify and quantify separately the effect of evaporative cooling in green roofs to further understand the impact that it has on the thermal performance of green roofs, but a closer look at their mathematical model raises questions of the accuracy of their conclusions. There is no information in the literature that isolates the effect of evaporation of water at the surface of the green roof, revealing its role in reducing the amount of heat transferred into the space below. Identifying this effect is important because it can be used in design settings for different buildings and climate conditions.

Chapter 2 examined the effect that the presence of evaporation has on the green roofs by comparing the energy balance of a system with and without evaporation. When there is no latent heat released at the soil's surface, the surface temperature would reach its maximum value. As can be seen in equation (5), the heat absorbed by convection to the green roof is conducted through the roof. In the next case all parameters are kept constant except there is evaporation. The release of latent heat, as evaporation, at the surface 
decreases the surface temperature of the soil. Then, a portion of the energy absorbed by convection is released as latent heat, and the rest is transferred through the roof.

The purpose of this study is to evaluate the effect that evaporative cooling has on the thermal performance of green roofs. Evaporative cooling was evaluated by comparing the results of a green roof slab experiment designed to impede evaporation of water in the surface of the slab to the results of the same green roof slab experiment where evaporation occurred at the surface. With the testing conditions kept constant throughout the experiments, except for evaporation, the difference in the heat transferred into the slab and in the temperature at the surface of the slab would correspond to the evaporative cooling component of the system. If evaporative cooling contributes to the reduction of heat transferred into the space below, the heat flux into the slab would decrease because latent heat is being absorbed from the atmosphere by the evaporation process occurring at the surface, and the surface temperature would decrease due to the cooling effect of evaporation at the surface.

To accurately determine the magnitude that evaporative cooling has on the thermal performance of green roofs, it was important to develop an experiment where the parameters that have been determined to affect the heat transfer processes in green roofs are kept constant so that the role of 
evaporative cooling can be assessed. These parameters include atmospheric temperature, temperature at the bottom of the green roof, thermal conductivity of the material, wind velocity and radiation. 


\section{METHODS AND EXPERIMENT}

\subsection{Materials}

The porous media used in green roofs is soil, which consists of mineral elements of variable thickness that differ in their morphological, physical, chemical, and mineralogical characteristics, therefore lacking homogeneity. Since the intention of this study was to conduct experiments where the evaporation rate was constant, and the soil's variability could impede this objective, the use of soil was discarded.

The experiments required the use of porous materials with the ability to retain water and that have good capillary transport properties to sustain the evaporation of water at the surface of the slab. A material that is able to retain water would have a structure of voids that can be filled with the fluid to ensure that water is available to maintain a continuous water supply from the capillaries. A material with good capillary transport would have a network of channels that allow for the constant movement of water to the surface of the material.

Research for materials that meet these requirements resulted in the use of sponges and wet floral foam for the tests. Sponges consist of porous material like cellulous wood fibers, known for their ability to retain water and water- 
based solutions. The water storage capability of a sponge is determined by the size of the void in the material.

The sponges used in the experiments were common kitchen sponges $(\mathrm{O}-$ cel-o) widely available in stores. Each sponge measured $10.2 \mathrm{~cm} \times 15.2 \mathrm{~cm}$ in area and $2.5 \mathrm{~cm}$ in depth. The average pore diameter of the material is approximately $140 \mu \mathrm{m}$. The media pore diameter was determined by measuring the pores' diameters visible under a microscope and averaging their value. A close-up image of the material under a microscope is shown in Figure 3. Each tray of sponge required 6 liters of water to reach saturation. Given that the sponges are made from wood fibers, it is assumed that its emissivity is comparable to that of wood, which is between 0.86-0.9 depending on the type of wood used.

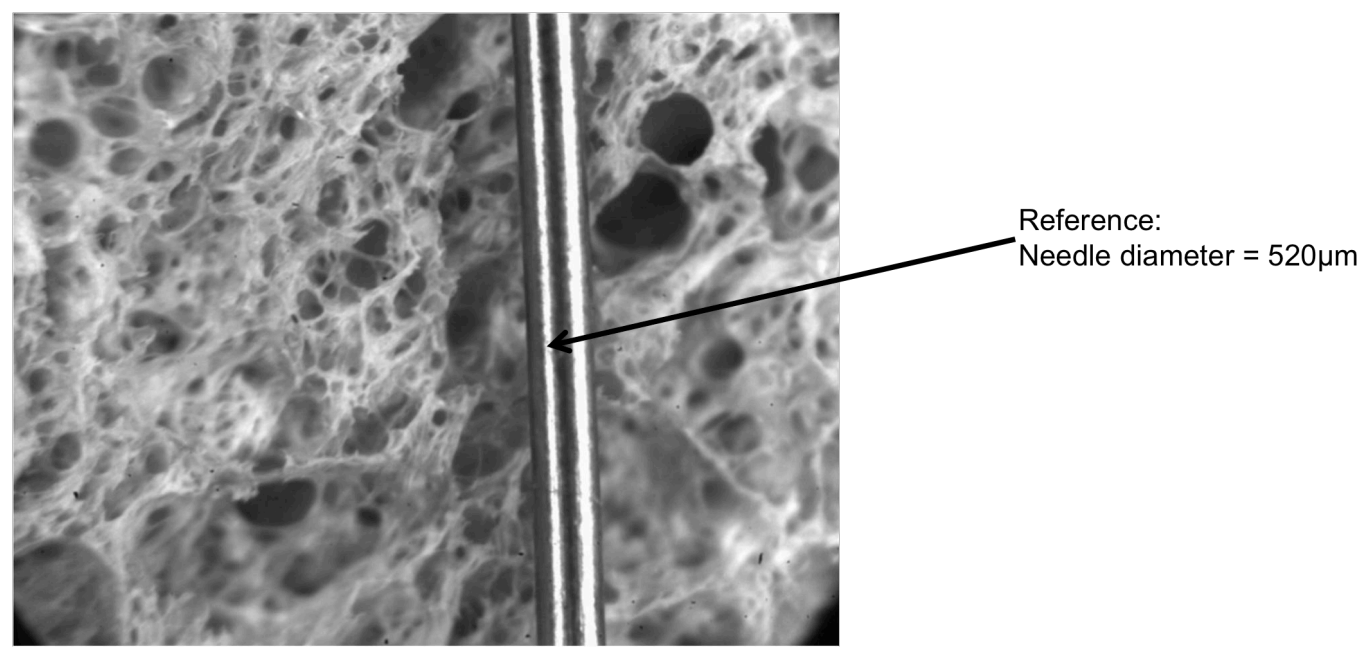

Figure 3. Image of the sponge's pores under a microscope 
The foam used on the experiments was wet floral foam (Oasis) available in most florist stores. They are commonly used in fresh flower arrangements for their ability to store water and continuously supply water to a fresh cut flower. Each floral foam measured $22.9 \mathrm{~cm} \times 7.6 \mathrm{~cm}$ in area and $2.5 \mathrm{~cm}$ in depth. The pore average diameter of the floral foam is approximately $100 \mu \mathrm{m}$. The average pore diameter was calculated the same way as for the sponges. Figure 4 is an image of the floral foam under a microscope. Each tray with floral foam required 9 liters of water to reach saturation. Since the floral foam is made from a phenol-based plastic, it is estimated that its emissivity is comparable to that found in Polyvinyl Chloride(P.V.C) which is about 0.9 .

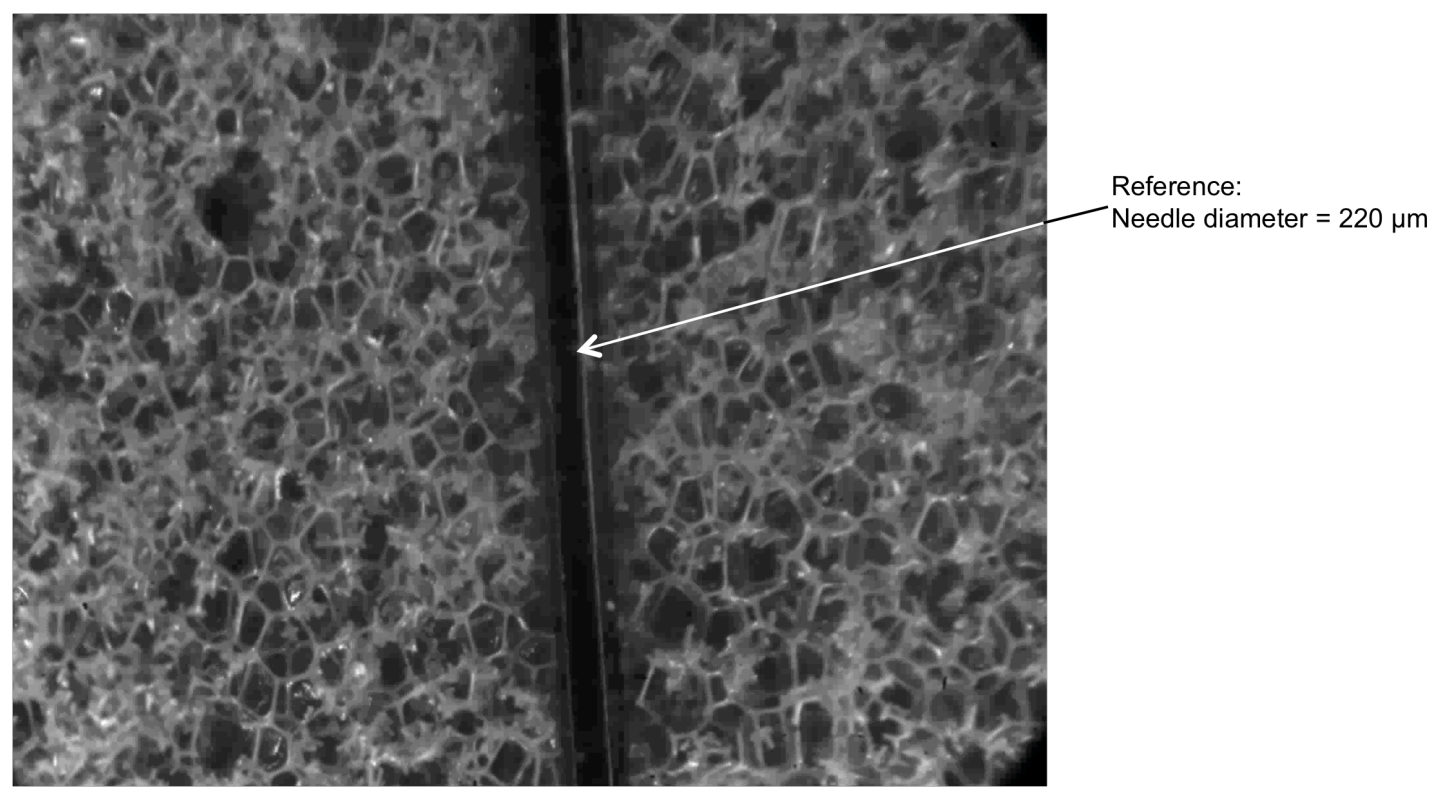

Figure 4. Image of the floral foam's pores under a microscope 
Comparing the total amount of water needed to saturate the sponge (6L) to the total needed to saturate the floral foam $(9 \mathrm{~L})$ indicates that the floral foam has a higher pore volume than the sponge. Since it required $3 \mathrm{~L}$ more of water to saturate the same volume of floral foam, it means that this material has a much higher fraction of this material is void space. The difference in moisture content between floral foam and sponge would affect the thermal performance of the materials. It has been shown that moisture content in soil --a porous media-- affects thermal conductivity of the soil (Sailor, 2008). The increase of moisture content in porous media results in higher thermal conductivity, thus increasing the heat transmitted through the soil. Since sponge and floral foam are porous media, the difference in moisture content between them would affect the heat transfer behavior during the experiments.

The effect on the radiation exchange between surfaces was considered. Sponge's emissivity is estimated to be between $0.86-0.90$. The emissivity for floral foam and the clear plastic wrap is estimated to be about 0.9 since the two are plastic-based. According to Kirchhoff's law, at thermal equilibrium, the emissivity of a body equals its absorptivity. Based on this information, it is assumed that the use of the three materials (sponge, floral foam, and plastic wrap) will not significantly change the radiation exchange between the surfaces. 


\subsection{Equipment}

The Green Roof Test and Design lab at Portland State University contains a testing unit (GERTY) designed to carry out heat transfer and water management experiments simulating a green roof on top of a building. The apparatus allows for the re-creation of a rooftop environment under controlled conditions (Figure 5). Air heated by an electrical heater flowed through the upper section at a constant temperature to simulate outdoor summer conditions. Cold air supplied by an air conditioner flowed through the lower section to simulate an air-conditioned space under the roof. A thin metal sheet separated the cold and hot sections.

The wind velocity inside the hot section of the tunnel is $5 \mathrm{mph}$, which is comparable to average wind velocities in summer months found in cities across the United States.

For all experiments, two identical trays with sponges or wet floral foam were assembled. Both identical trays filled with testing material were placed on the shelf between the hot and cold sections. The trays measured $61 \mathrm{~cm} x$ $61 \mathrm{~cm}$ in area and $2.5 \mathrm{~cm}$ in height. 


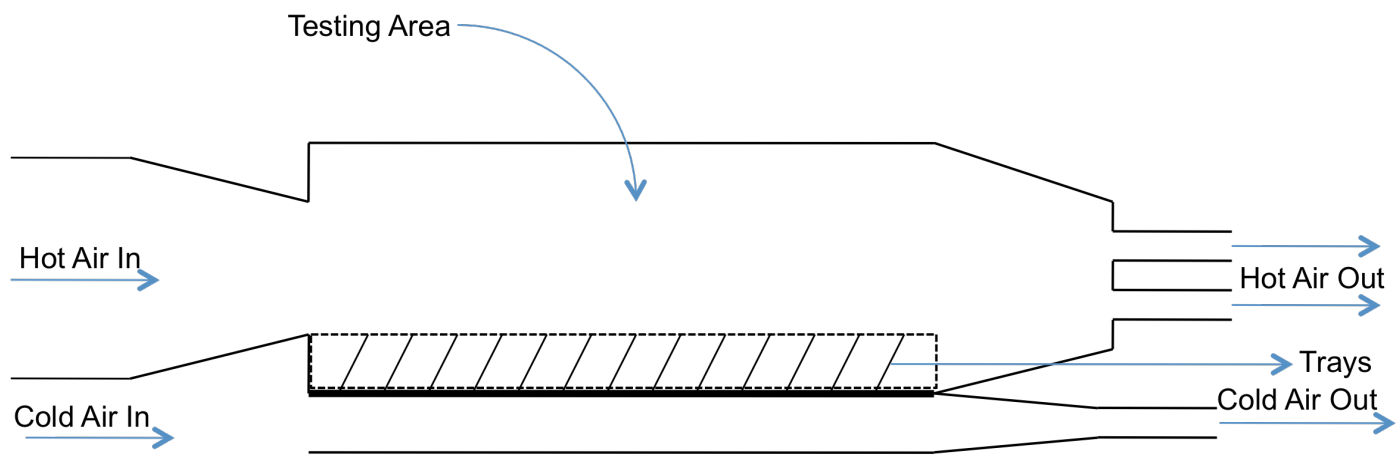

Figure 5. Cross sectional view of the testing unit (GERTY)

\section{$\underline{\text { Thermocouples }}$}

Type $T$ thermocouples were used to measure the air temperature in the hot and cold section, and at the surface of the material. A thermocouple is installed under each tray inside the cold section and above each tray in the hot section (Figure 6). To measure the surface temperature of the material, a thermocouple was placed at approximately the center of each tray. Special care was taken to make sure that the tip of the thermocouple and the surface of the material were in direct contact. To ensure that these sensors did not move over the course of the test, they were held in place with a U-shaped cord. Type $\mathrm{T}$ thermocouples are suited for measurements in the $-200^{\circ} \mathrm{C}$ to $350^{\circ}$ range. The standard limit of error is $\pm 1^{\circ} \mathrm{C}$. 


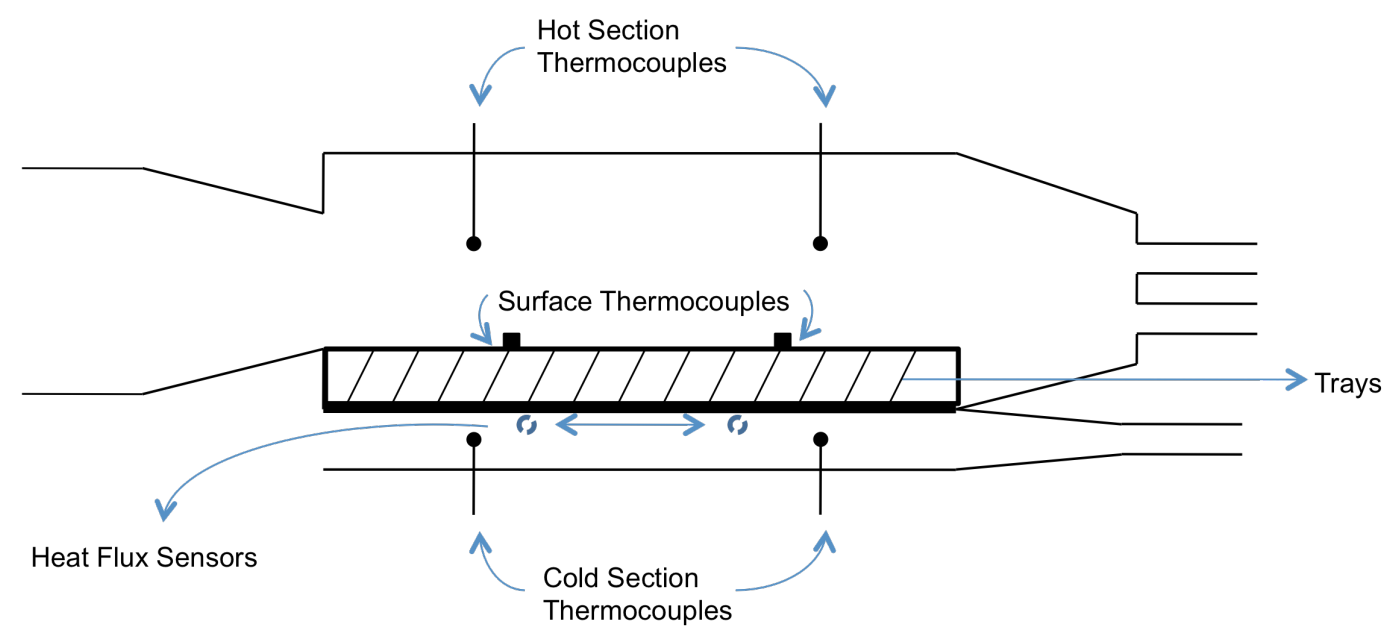

Figure 6. Locations of thermocouples and heat sensors in the testing unit.

\section{$\underline{\text { Heat Flux Sensors }}$}

Heat flux is the rate of energy, in the form of heat, passing through a surface per unit area. Units are $\mathrm{W} / \mathrm{m}^{2}$. Heat flux sensors (Vatell BF03) were located underneath the sheet metal separating the hot and cold sections corresponding to the center of each of the two trays (Figure 6). The sensors are rated at a sensitivity of $76.42 \mathrm{mV} / \mathrm{W} / \mathrm{cm}^{2}$.

\section{Weight Scale}

Weight of the sponges and floral foam trays was measured during the experiments using load cells installed under the four corners of the test bed. The weight recorded was the total weight of both testing trays combined. The load cells are (Transducer) Omegadyne Inc. Brand, Model LC305-100, and 
are calibrated to be accurate from 0.00 to $100.00 \mathrm{lbs} \pm 0.25 \%$ with an operating temperature range of $16^{\circ} \mathrm{C}$ to $71^{\circ} \mathrm{C}$.

\section{Data Acquisition System}

A National Instruments Compact DAQ NI cDAQ 9172 data acquisition system connected to a Dell Latitude E5400 laptop running LabVIEW Single Express Project version 3.0 was used to collect and monitor temperature, heat transfer and weight data. The sampling rate was fixed at $1613 \mathrm{~Hz}$ resulting in 16130 samples every 10 seconds.

$\underline{\text { Trays }}$

The trays used in this study were made from steel. Dimensions of the trays were 24" x 24"x 1". Each tray had a 1" diameter drain hole drilled on one end that directed all excess water into a capture container.

\subsection{Experimental Procedure}

To evaluate the effect that evaporative cooling has on green roofs, two experiments that allow for a direct comparison of a green roof surface with and without evaporation were designed.

A typical experiment started with two sponge or foam trays being placed into the testing unit. Each tray was filled until water was observed to be above the surface of the material. Since the thermal conductivity of porous media is 
proven to change with moisture content (Sailor, 2008), all experiments were conducted with the sponges and floral foam saturated with water to ensure that the thermal conductivity of the materials did not change. The excess water was drained. When water stopped draining from each tray, it was assumed the material was saturated with water.

For the experiments with evaporation, the sponges and foam trays were placed in the testing unit and left uncovered to allow surface evaporation. For the experiments without evaporation, a thin layer of clear plastic wrap was carefully and tightly placed on the surface of the material to prevent evaporation of the water from the materials. The plastic wrap provided an impervious layer to block water evaporation with little insulating potential to alter the conductive heat flow. Pictures of a sponge and floral foam filled trays in the testing unit ready for testing are shown in Figures 7 and 8.

During testing, the hot air was held constant at $38^{\circ} \mathrm{C}$ while the cold side was held at $8^{\circ} \mathrm{C}$. Relative humidity depended on the moisture ambient air in the room and it ranged between 15\%-25\% inside the test unit. Sponge tests were 7 hours long while floral foam tests were 14 hours long to allow for steady state to be reached, and to capture a significant amount of data under that condition. The measured and recorded data included temperatures in the hot and cold sections of the unit, surface temperature of the material, heat conducted through the material, relative humidity and weight. By doing a 
visual examination of the data recorded for temperatures in the hot and cold sections and for the heat flux, it was determined that steady state was achieved at hour 3 of the sponge tests, and at hour 8 of the floral foam tests. The data was averaged to provide a mean value for each recorded parameter.

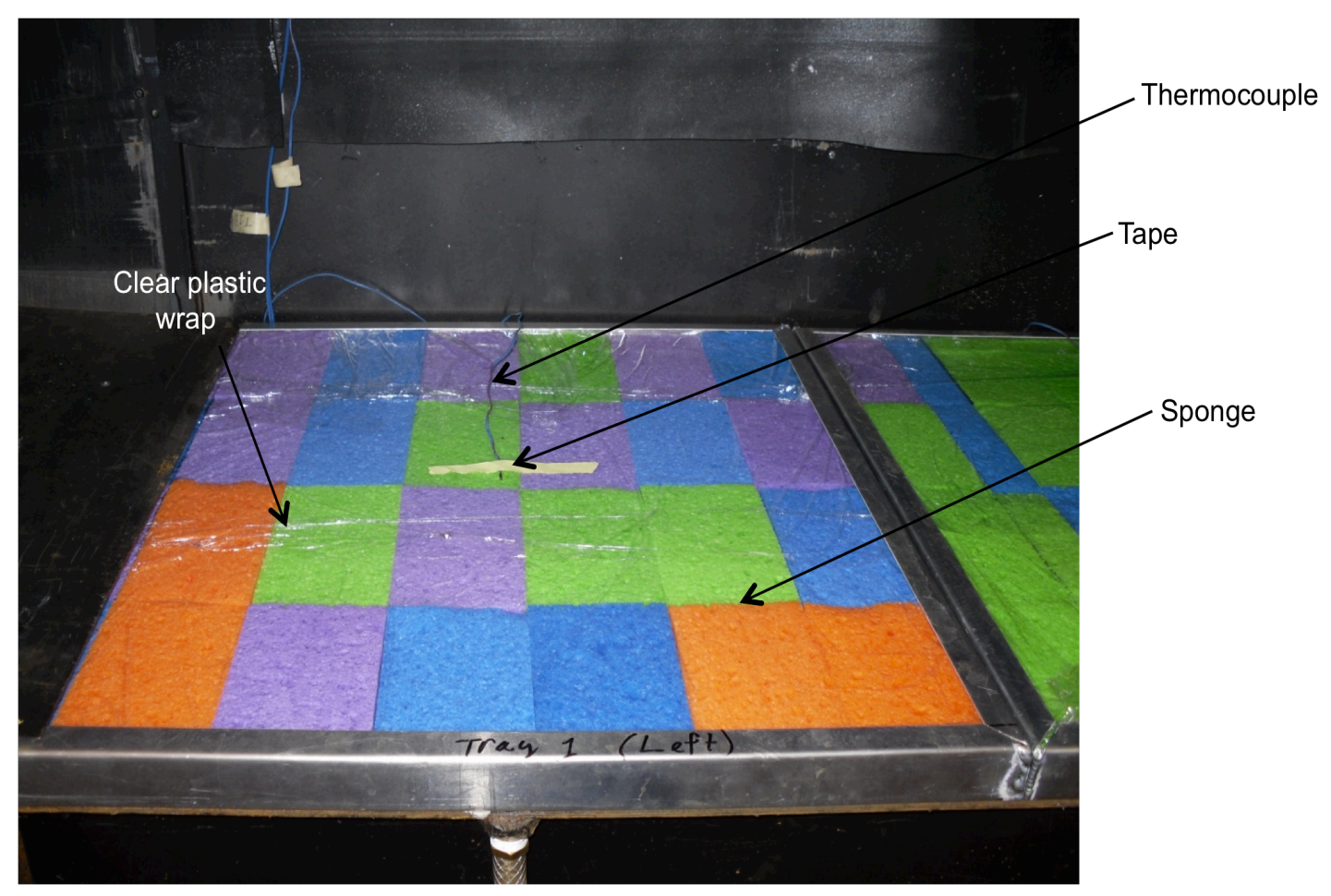

Figure 7. Image of sponge filled tray in the testing unit 


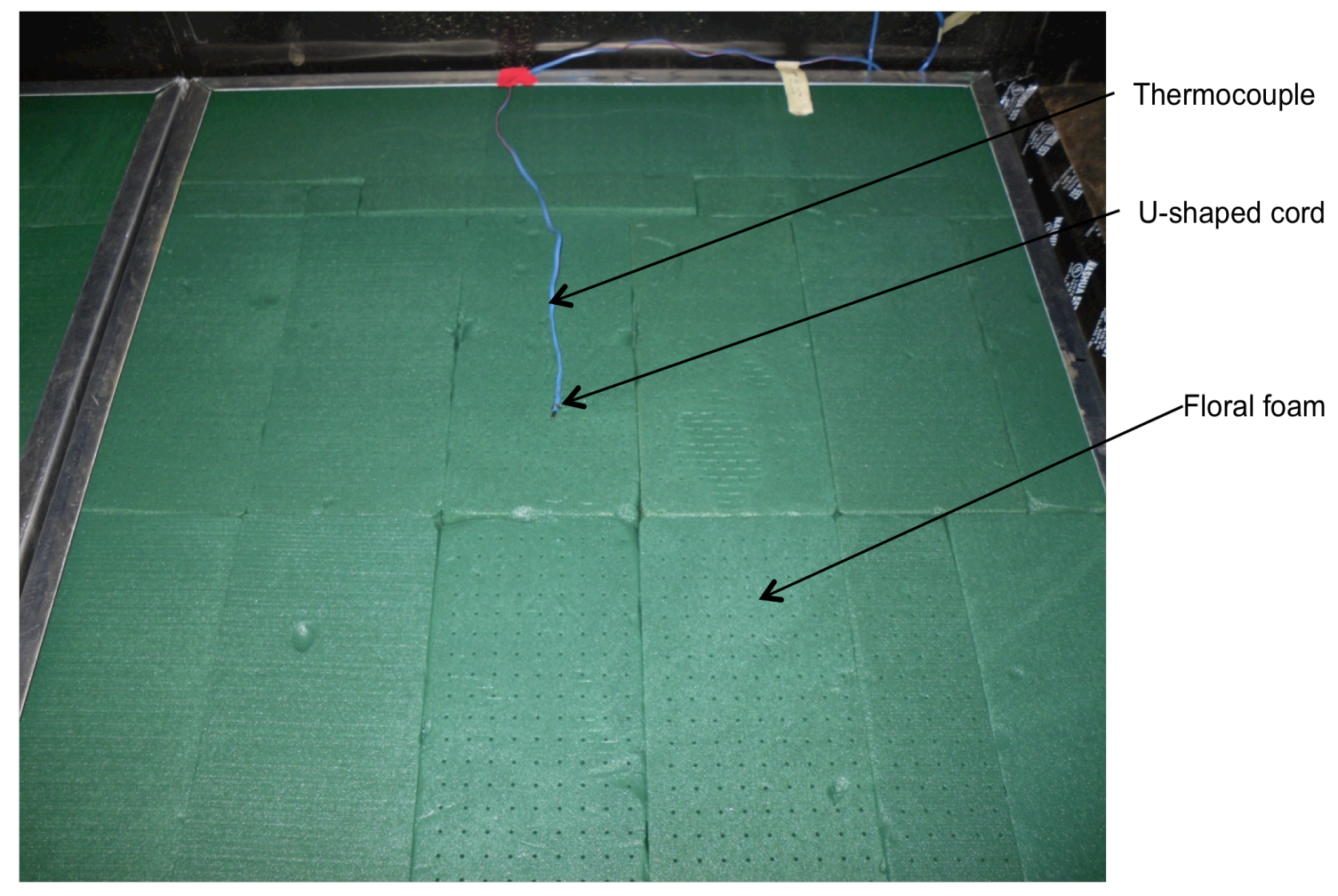

Figure 8. Image of floral foam filled tray in the testing unit 


\section{RESULTS AND DISCUSSION}

\subsection{Evaporation}

Weight change charts for the two materials tested, sponges and floral foam, are presented in Figure 9.

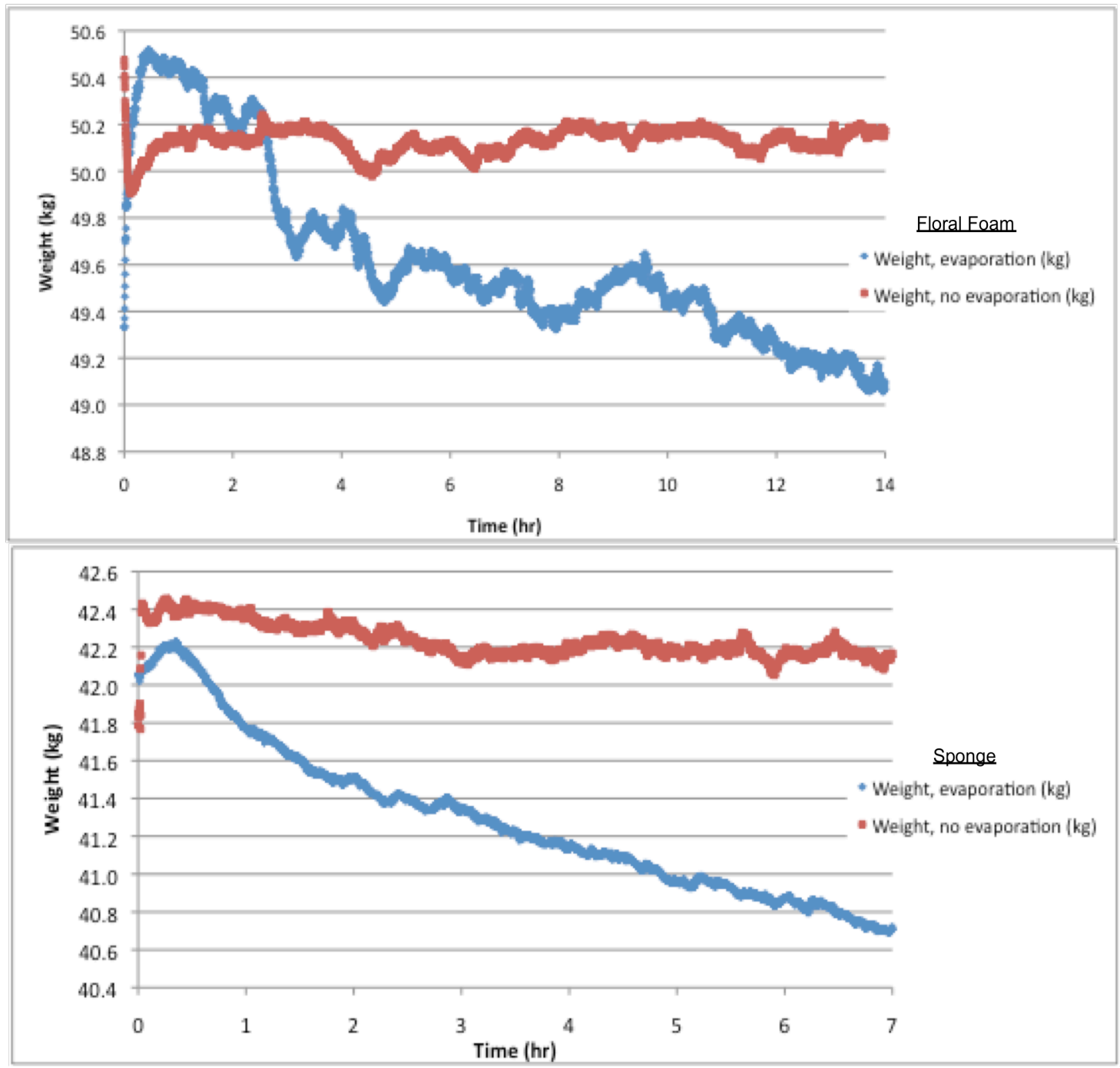

Figure 9. Weight changes of the tested porous materials 
The weight of the trays filled with floral foam and sponges that were covered remained constant during the time of the experiments, as can be seen by the essentially flat weight curve in Figure 9. The use of plastic wrap successfully blocked the evaporation at the surface of the material. The weight of the trays that were not covered, by contrast, evaporated water throughout the duration of the experiments at more or less a constant rate, as observed by the linear decline of weight with time in Figure 9 . Summaries of the evaporation rates derived from the experiments are presented in Table 2. Sponge trays evaporated $1.5 \mathrm{~kg}$ of water during the 7 hours of experimentation, while floral foam trays evaporated $1.4 \mathrm{~kg}$ of water during a 14 hours experiment. Sponges had evaporation rate twice that of floral foam (sponges $0.29 \mathrm{~kg} / \mathrm{m}^{2} \mathrm{hr}$ and floral foam $0.14 \mathrm{~kg} / \mathrm{m}^{2} \mathrm{hr}$ ).

Table 2. Evaporation rates for sponge and floral foam

\begin{tabular}{lcc}
\hline Material & Sponges & Floral Foam \\
\hline Experiment Lengh (hours) & 7 & 14 \\
Initial trays weight $(\mathrm{kg})$ & 42.2 & 50.5 \\
Final trays weight $(\mathrm{kg})$ & 40.7 & 49.1 \\
Amount of evaporated water $(\mathrm{kg})$ & 1.49 & 1.41 \\
Evaporation rate $\left(\mathrm{kg} / \mathrm{m}^{2} \mathrm{hr}\right)$ & 0.29 & 0.14 \\
\hline
\end{tabular}


The work of Wanphen and Nagano (2009) found evaporation rates very similar in magnitude to the results of this study. The use of materials with diameters of $0.14 \mathrm{~mm}$ and $0.10 \mathrm{~mm}$ which are much smaller compared to the materials used by Wanphen and Nagano, which ranged from $4 \mathrm{~mm}$ to $10 \mathrm{~mm}$, found evaporation rates comparable to those found by the authors. However, the trend seen in Wanphen and Nagano's result is larger evaporation rates with the smaller pores. In this study, materials with much smaller pores were used. Results show that the largest evaporation rate was found with sponge.

\subsection{Heat Transfer}

The effect of evaporative cooling on the heat transferred through sponge and floral foam was evaluated by comparing the steady state heat transfer data collected during the experiments with and without evaporation. In the

floral foam experiments, 8 hours of steady state data collected from the pair of heat flux sensors were averaged to obtain the average steady heat transfer. Similarly, in the sponge experiments 4 hours of steady state data were averaged. Hence, each experiment was replicated for each material. Results of the average heat transfer through the materials with or without evaporation are presented in Table 3. The raw data is available in Appendix A. 
Table 3. Average heat transferred through the material

Average Heat Transferred through the material

No-Evaporation Evaporation

\begin{tabular}{ccc} 
& $\left(\mathrm{W} / \mathrm{m}^{2}\right)$ & $\left(\mathrm{W} / \mathrm{m}^{2}\right)$ \\
\hline Floral Foam & $132 \pm 4$ & $67 \pm 4$ \\
Sponge & $76 \pm 4$ & $38 \pm 4$ \\
\hline
\end{tabular}

The results for both sponge and floral foam show that when evaporation of water occurred, there was a reduction of heat transferred through the slab of material. For sponge, the heat transferred was reduced by $50 \%$ due to evaporative cooling. For floral foam, heat transfer was reduced by $49 \%$ due to evaporative cooling. This reduction in heat flux due to evaporation at the surface is due to the latent heat absorbed during the evaporation process.

When comparing heat transfer results between the two porous materials tested, floral foam and sponge, there is an evident difference between them. In both cases, with and without evaporation, sponge had a $42-43 \%$ less heat transmitted through the roof when compared to floral foam. This is likely due to foam's higher thermal conductivity due to higher moisture content. Floral foam had $50 \%$ more water at the start and end of the experiments compared to 
sponge. A high thermal conductivity resulted in higher heat conducted through floral foam.

From these results, it is implied that to obtain the best thermal performance from green roofs the soil must have the characteristics that the best performer material, sponge, had in this study, which is large pores and small field capacity. The soil will enhance water transport through its body to ensure evaporation at the surface. The release of latent heat through evaporation will significantly reduce the heat transmitted through the roof.

The statistical significance of the data was evaluated using a two sample t-test using Minitab Statistical Software. This test allows for a comparison of the average difference between the two scenarios tested for each material, with and without evaporation, to determine whether the difference in the results are statistically significant or whether it is due to random chance. The tested hypothesis was that there was a significant difference between the results with and without evaporative cooling, and the null hypothesis was that there was no difference.

Results from the two sample t-test done on the floral foam data showed that using a significance level of $95 \%$ the null hypothesis is rejected. There is a significant difference in heat flux when there is evaporation at the surface. The statistical program estimated the difference to be $61 \mathrm{~W} / \mathrm{m}^{2}$ with a $p=0.000$. A smaller $p$-value, often defined as $p<0.050$, indicates a strong relationship 
between the variable and the outcome. An individual value plot with the data collected from the experiments with and without evaporation using floral foam is shown is Figure 10. This plot shows the sample distributions through individual data values. The vertical bars display all values collected during steady state for the two experiments done with floral foam, with and without evaporation and shows the variation in the data. The line connecting the mean value of the two sets, represent the significant difference between the two results.

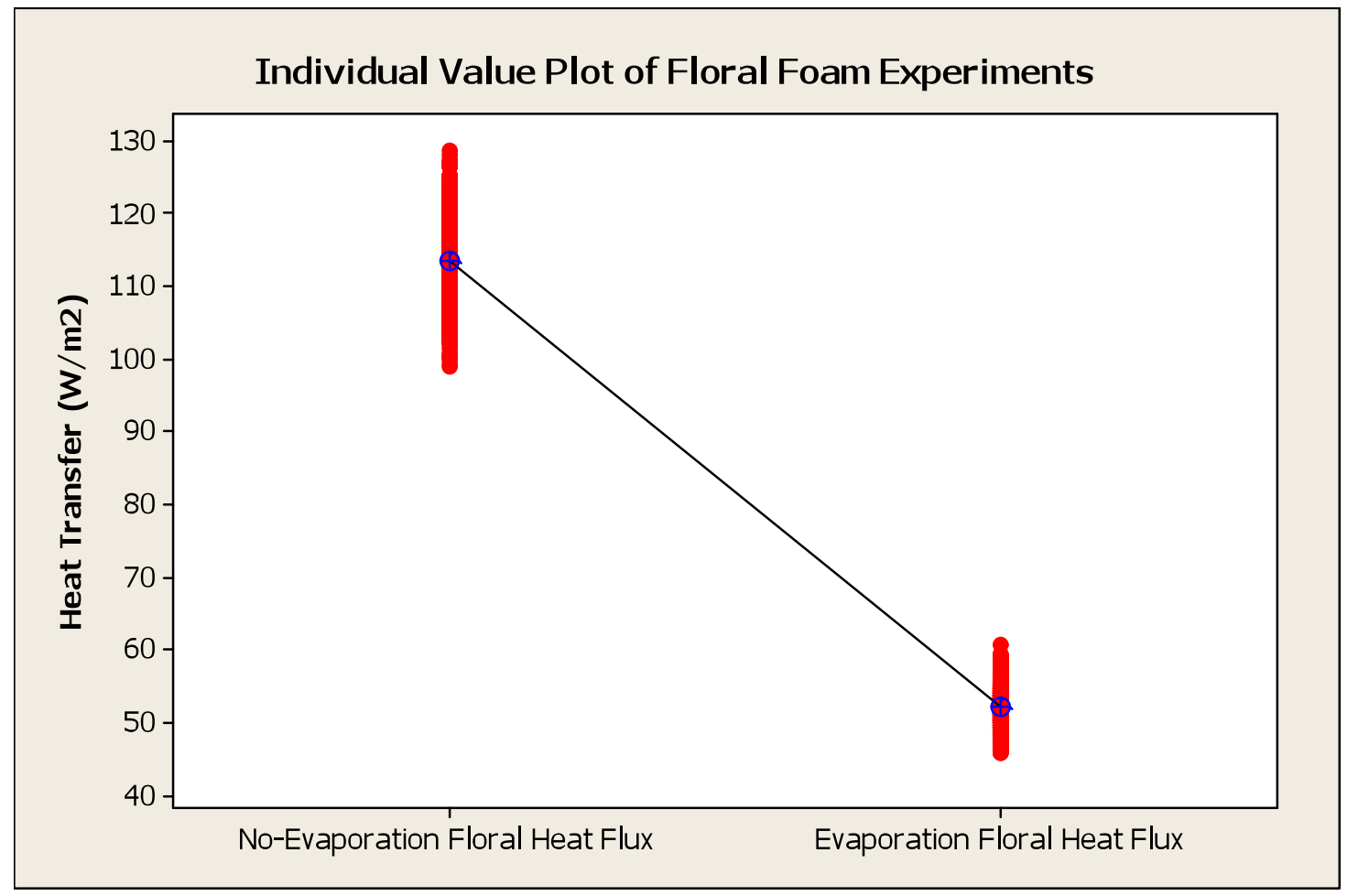

Figure 10. An individual value plot of the data collected in the experiments with and without evaporation of water at the surface using floral foam. 
An evaluation of the statistical significance of the heat transfer results found during the sponge experiments was also done using a two sample t-test. It concluded that using a $95 \%$ confidence level, the reduction in heat flux transferred through the slab of sponge when there is evaporation of water at the surface is statistically significant. The statistical program estimated the difference to be $30 \mathrm{~W} / \mathrm{m}^{2}, p=0.000$. An individual value plot with the data collected from the experiments with and without evaporation using floral foam is shown in Figure 11. The complete results for all statistical analysis in this study can be found in Appendix B.

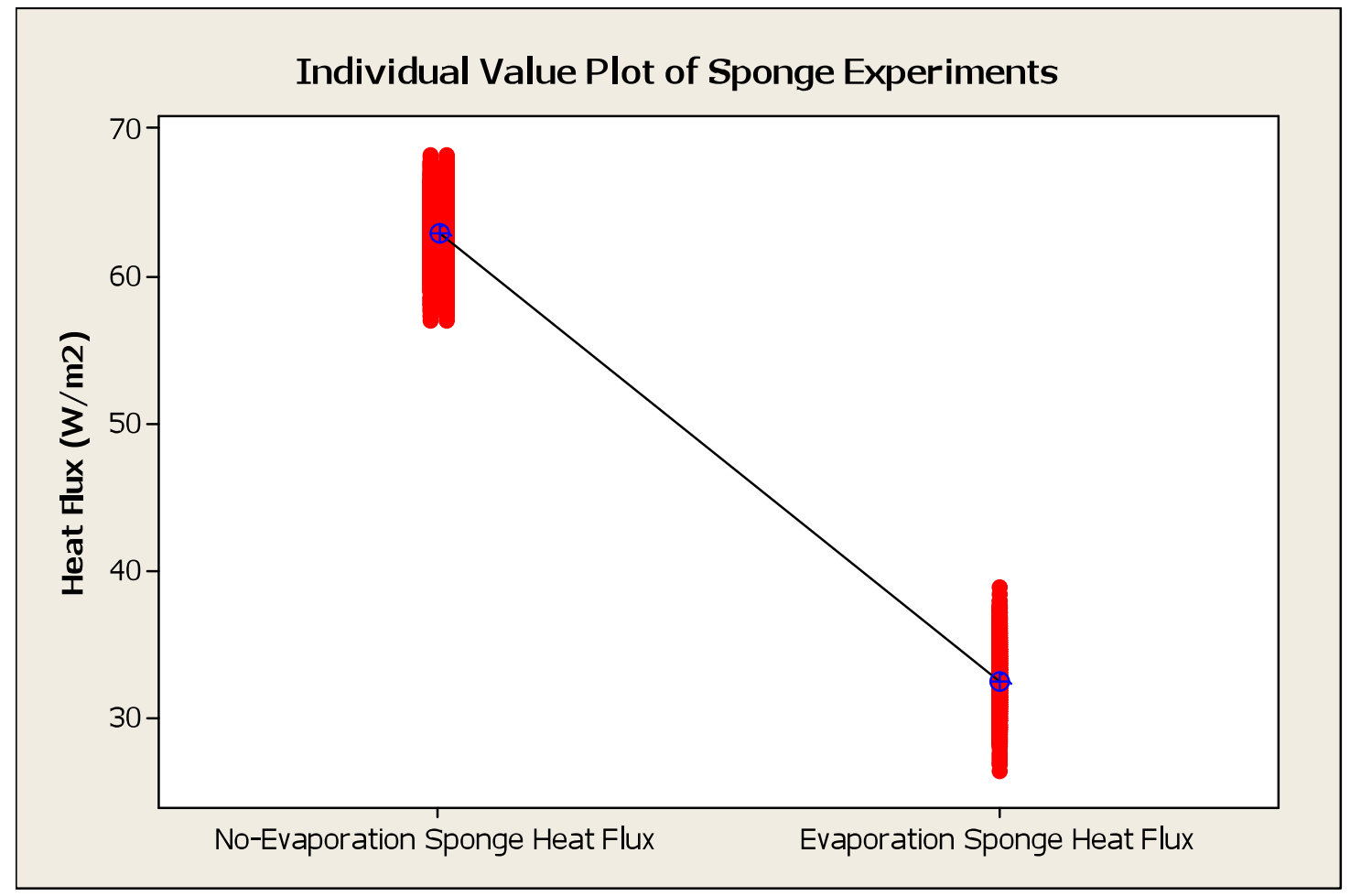

Figure 11. An individual value plot of the data collected in the experiments with and without evaporation of water at the surface using sponge. 


\subsection{Temperature}

Temperatures were measured in the hot and cold section of the testing unit and on the surface of the materials, floral foam and sponges, during the experiments with and without evaporation. Figure 12 shows the temperatures of the surface of the materials during the duration of the tests. Average temperatures of the experiments, with or without evaporation using the two tested materials are present in Table 4. Raw temperature data is available in Appendix A.

The results show that during the evaporation experiments, the surface temperatures of the sponge and floral foam were lower when evaporation was occurring. Sponge's surface temperature decreased $7^{\circ} \mathrm{C}$ when there was evaporation, and floral foam's surface temperature decreased $2^{\circ} \mathrm{C}$. The larger surface temperature reduction observed in sponge tests is explained by a larger evaporation rate found in the sponge tests. During the evaporation of water, latent heat is released to the atmosphere resulting in a cooling effect at the surface of the material. These results are consistent with the temperature depression found by Tang and Jiang (2009) where they found a temperature reduction of $4^{\circ} \mathrm{C}$ between a green roof surface and a concrete roof. 
Table 4. Average surface temperatures of sponge and floral foam

\begin{tabular}{lcccc}
\hline \multicolumn{1}{c}{$\begin{array}{c}c \\
\text { Average }\end{array}$ Temperature } & Covered & Uncovered & Covered & Sponges \\
& $\left({ }^{\circ} \mathrm{C}\right)$ & $\left({ }^{\circ} \mathrm{C}\right)$ & $\left({ }^{\circ} \mathrm{C}\right)$ & $\begin{array}{c}\text { Uncovered } \\
\left({ }^{\circ} \mathrm{C}\right)\end{array}$ \\
\hline At Hot Section & 37 & 37 & 37 & 37 \\
At Surface & 19 & 17 & 22 & 15 \\
At Cold Section & 8 & 8 & 9 & 8 \\
\hline
\end{tabular}

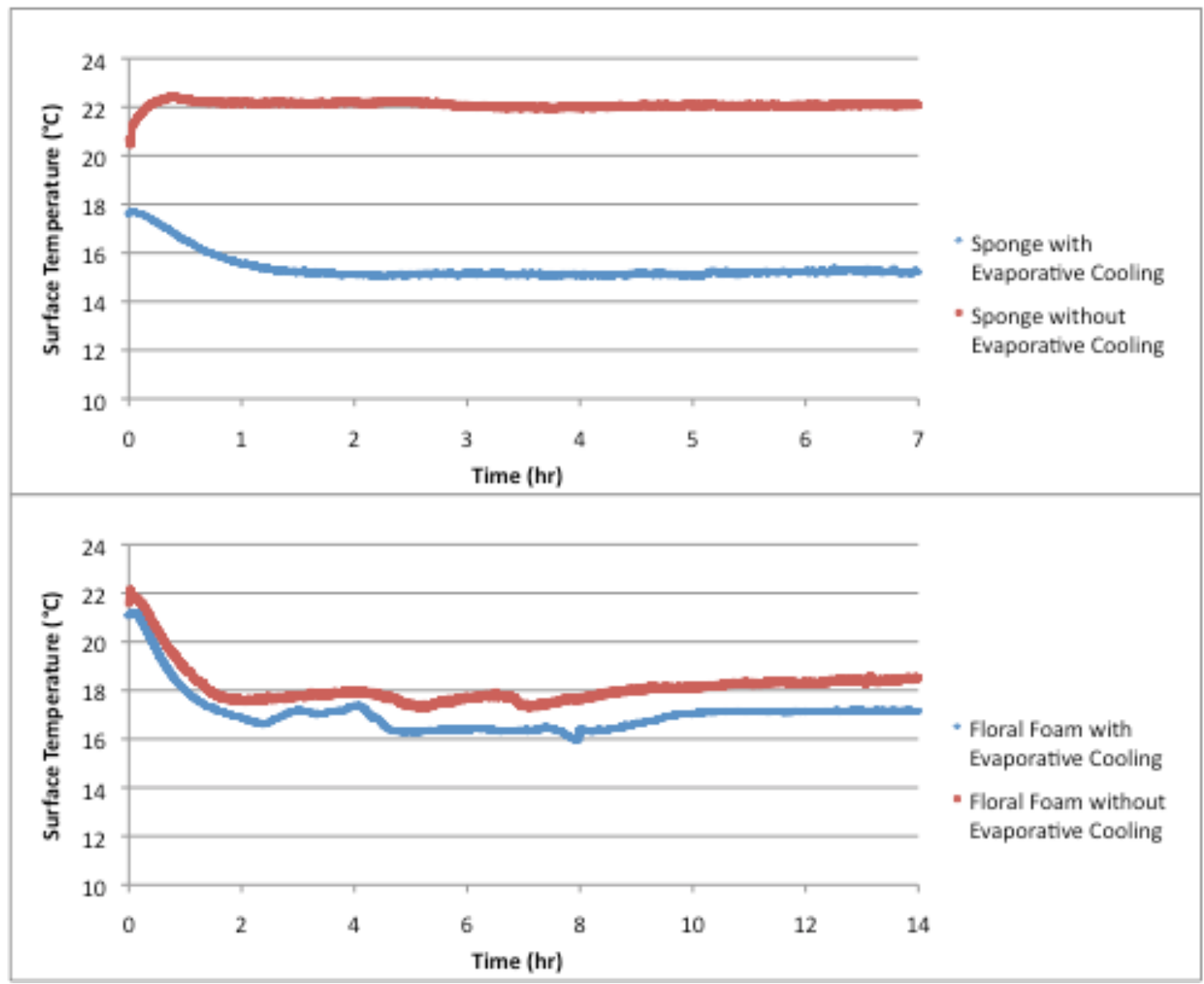

Figure 12. Surface temperature over time for the experiments with and without evaporative cooling using floral foam and sponge. 


\subsection{Comparison of Model vs. Experimental Results}

The evaporation rates obtained through experimentation were compared against the evaporation rates predicted by the model. The predicted evaporation rates were found by using equation 1 to calculate the convective heat transfer coefficient of the green roof.

Equation 1

$$
h=\frac{q_{c o n v}}{\left(T_{\infty}-T_{s}\right)}
$$

Where: $\quad h=$ convective heat transfer coefficient

$\mathrm{q}_{\mathrm{conv}}, \mathrm{T}_{\infty}$, and $\mathrm{T}_{\mathrm{s}}=$ measured experimentally during the experiments without evaporative cooling

Since the ambient conditions were kept constant during all experiments, it was assume that the convective heat transfer coefficient (h) is constant for the experiments with and without evaporation. Then, by rearranging equation 6 , the model's predicted evaporation rates were calculated.

\section{Equation 6}

$$
\dot{m}=\frac{1}{h_{f g}}\left[h\left(T_{\infty}-T_{s}\right)-q_{c o n d}\right]
$$

Where: $\quad h=$ calculated heat transfer coefficient

$$
\mathrm{T}_{\infty} \text {, and } \mathrm{T}_{\mathrm{s}}=\text { measured experimentally during the experiments. }
$$


$\mathrm{q}_{\mathrm{cond}}=$ measured experimentally as the heat transfer conducted through the roof with evaporative cooling.

The experimental evaporation rates results were compared to the predicted evaporation rates from the green roof model. The predicted and experimental evaporation rates are presented in Table 5.

Table 5. Predicted and experimental evaporation rates results

\begin{tabular}{ccc}
\hline \multicolumn{3}{c}{$\begin{array}{c}\text { Evaporation Rates } \\
\left(\mathrm{Kg} / \mathrm{m}^{2} \mathrm{hr}\right)\end{array}$} \\
\hline & Predicted by Model & Experimental \\
\hline Floral Foam & 0.113 & 0.14 \\
Sponge & 0.103 & 0.29 \\
\hline
\end{tabular}

The evaporation rate of floral foam found by experimentation is comparable to the evaporation rate predicted by the model. However, the experimental evaporation rate of sponge is $180 \%$ higher than predicted. The model predicted a higher evaporation rate for foam than sponge, but experimental results show the opposite trend, where sponge evaporates at a faster rate than floral foam. The reason for these discrepancies cannot be explained conclusively. A plausible explanation is that the surface temperature measured during the experiments using sponge with evaporative cooling was 
higher than the true temperature at the surface of the sponge due to the difficulty in defining the "surface" of the porous media. The tip of the sensor is about $2 \mathrm{~mm}$ diameter and sponge has pores larger than $2 \mathrm{~mm}$. It is possible that the sensor was sitting in air instead of on the actual surface, which resulted in a higher temperature being recorded. If the sensor recorded a higher temperature than the actual surface temperature of the material, the predicted evaporation rate would be lower than the actual evaporation rate. 


\section{CONCLUSION}

Two porous materials with different pore diameters, sponge and floral foam, were subjected to evaporation and no evaporation experiments to evaluate their thermal performance. The evaporation rates of sponge and floral foam were $0.29 \mathrm{~kg}$ water $/ \mathrm{m}^{2} \mathrm{~h}$ and $0.14 \mathrm{~kg}$ water $/ \mathrm{m}^{2} \mathrm{~h}$, respectively, which is comparable to similar results found for porous materials with larger diameters. Floral foam's evaporation rate was lower, however it required $50 \%$ more water to reach saturation than sponge. Comparison of the evaporation rates predicted by the model and the experimental results show good agreement with floral foam, however sponge's evaporation rate was $180 \%$ higher than predicted by the model.

Results of heat flux show that evaporation at the surface significantly reduces the amount of heat transmitted through the roof, by about $50 \%$. For sponges, heat transferred without evaporation was $76 \mathrm{~W} / \mathrm{m}^{2}$, and with evaporation it was $38 \mathrm{~W} / \mathrm{m}^{2}$. For floral foam, heat flux without evaporation was $132 \mathrm{~W} / \mathrm{m}^{2}$, while it was $67 \mathrm{~W} / \mathrm{m}^{2}$ with evaporation. Floral foam had higher heat transferred through the material due to a higher thermal conductivity.

Evaporation contributed to the reduction of the surface temperature of the materials. A reduction of $2^{\circ} \mathrm{C}$ was recorded for floral foam with evaporation at the surface, and a reduction of $7^{\circ} \mathrm{C}$ was found for sponge. 
Therefore, in green roof design, the optimal performance will be found using materials that enhances water transport to the surface to ensure evaporation, and have the sponge characteristics of large pores and low field capacity.

For the next steps for this research, the effect of pore size in the evaporation rate of porous media can be further investigated by using sponge with varying pore sizes. 


\section{REFERENCES}

Bass, B., Baskaran, B., 2003. Evaluating rooftop and vertical gardens as an adaptation strategy for urban areas. Institute for Research and Construction. NRCC-46737. Project no. A020. CCAF Report B1046. National Research Council. Ottawa, Canada.

Beckett, K.P., Freer-Smith, P., Taylor, G., 1998. Urban woodlands: their role in reducing the effects of particulate pollution. Environmental Pollution 99, 347-360.

Bell, H.J., 2009. Measured energy performance of green roofs. Master Degree Thesis. Portland State University. Portland, OR.

Brenneisen, S., 2006. Space for urban wildlife: Designing green roofs as habitats in Switzerland. Urban Habitats 4, 27-36.

Coffaman, R., Davis, G., 2005. Insect and avian fauna present on the Ford assembly plant ecoroof. Paper presented at the Third Annual Greening Rooftops for Sustainable Communities Conference, Awards and Trade Show; 2-6 May 2005. Washington, DC.

Del Barrio, E., 1998. Analysis of the green roofs cooling potential in buildings. Energy and Buildings 27, 179-193.

Feng, C., Meng, Q., Zhang, Y., 2010. Theoretical and experimental analysis of the energy balance of extensive green roofs. Energy and Buildings 42, 959-965. 
Gaffin, S., Rosenzweig, C., Parshall, L., Beattie, D., Berghage, R., O'Keeffe, G., Braman, D., 2005. Energy balance modeling applied to a comparison of green and white roof cooling efficiency. Paper presented at the Third Annual Greening Rooftops for Sustainable Communities Conference, May 4-6 2005. Washington, DC.

Gaffin, S., Rosenzweig, C., Parshall, L., Hillel, D., Eichenbaum-Pikser, J., Greenbaum, A., Blake, R., Beattie, D., Berghage, R., 2006. Quantifying evaporative cooling from green roofs and comparison to other land surfaces. Paper presented at the Fourth Annual Greening Rooftops for Sustainable Communities Conference, May 11-12 2006. Boston, MA.

Hill, A.C., 1971. Vegetation: a sink for atmospheric pollutants. Journal of the Air Pollution Control Association 23, 341-346.

Hillel, D., 2003. Introduction to environmental soil physics. Amsterdam: Academic Press.

Incropera, F.P., Dewitt, D.P., 1996. Fundamentals of heat transfer. New York: Wiley.

Jarrett, A., Hunt, W., Berghage, R., 2006. Annual and individual-storm green roof stormwater response models. Paper presented in ASABE Annual International Meeting; JULY 9-12 2006 Portland, OR.

Kadas, G., 2006. Rare invertebrates colonizing green roofs in London. Urban Habitats 4, 66-86. 
Kosareo, L., Ries, R., 2006. Comparative environmental life cycle assessment of green roofs. Building and Environment 42, 2606-2613.

Lawrence Livermore National Laboratory (2009). Estimated U.S Energy Use 2009. Retrived July 31, 2010, from https://flowcharts.IInl.gov/

Lazzarin, R.M., Castellotti, F., Busato, F., 2005. Experimental measurements and numerical modeling on a green roof. Energy and Buildings 37, 1260-1267.

Moran, A., Hunt, B., Smith, J., 2005. Hydrologic and water quality performance from green roofs in Goldsboro and Raleigh, North Carolina. Paper presented at the Third Annual Greening Rooftops for Sustainable Communities Conference, Awards and Trade Show; 2-6 May 2005. Washington, DC.

Oke, T.R., 1987. Boundary layer climates. Methuen, London., $2^{\text {nd }}$ edition.

Onmura, S., Matsumoto, M., Hokoi, S., 2001. Study on evaporative cooling effect on roof lawn gardens. Energy and Buildings 33, 653-666.

Sailor, D.J., 2008. A green roof model for building energy simulation programs. Energy and Buildings 40, 1466-1478.

Sailor, D.J., Hutchinson., Bokovoy, L., 2008. Thermal property measurements for ecoroof soils common in western U.S., Energy and Buildings 40, 1246-1251. 
Saiz, S., Kennedy, C., Bass, B., Pressnail, K., 2006. Comparative life cycle assessment of green and standard roofs. Environmental Science and Technology 40, 4312-4316.

Santamouris, M., Papanikolaou, N., Livada, I., Koronakis, I., Georgakis, C., Argiriou, A., Assimakopoulos, D.N., 2001. On the impact of urban climate on the energy consumption of buildings. Solar Energy 70, 201-216.

Spolek, G., 2008. Performance monitoring of three ecoroofs in Portland, Oregon. Urban Ecosystems, 11, 349-459.

Taha, H., Akbari, H., Rosenfeld, A., 1989. Vegetation microclimate measurements: The Davis project. Lawrence Berkeley Laboratory Report no. 24593.

Taha, H., Rosenfeld, A., Akbari, H., 1991. Heat island and oasis effect of vegetative canopies: Micrometeorological field measurement. Theoretical and Applied Climatology 44, 123-138.

Tang M., and Jiang, L., 2009. Analysis on thermal measuring of green roof. Journal of Central South University of Technology 16, 150-153.

Theodisio, T.G., 2003. Summer period analysis of the performance of a planted roof as a passive cooling technique. Energy Buildings 35, 909-917.

United Nations, Population Division. World urbanization prospects: The 2007 revision. Retrived July 31, 2010, from http://esa.un.org/unup/ 
Wanphen, S., Nagano, K., 2007. Experimental study of the performance of porous materials to moderate the roof surface temperature by its evaporating cooling effect. Building and Environment 44, 338-351.

Yang, J., Qian, Y., Peng, G., 2010. Quantifying air pollution removal by green roofs in Chicago. Atmospheric Environment 42, 7266-7273. 


\section{APPENDIX A: Raw Test Results}

The test data collected during the evaporation and no evaporation experiments are included in Table A.1. Since each test was replicated, the letter "a" refers to the first test and the letter "b" refers to the second test of a given experiment with or without evaporation. Two sets of measurements were taken for each test. In the table, "1" refers to the data for the first tray and "2" refers to the data for the second tray. $T_{c}$ refers to the temperature measured in the cold section, $T_{h}$ refers to the temperature measured in the hot section, and $\mathrm{T}_{\text {surf }}$ refers to the temperature measured at the surface of the testing material. The heat flux refers to the heat conducted through the material and measured at the bottom of the tray. 


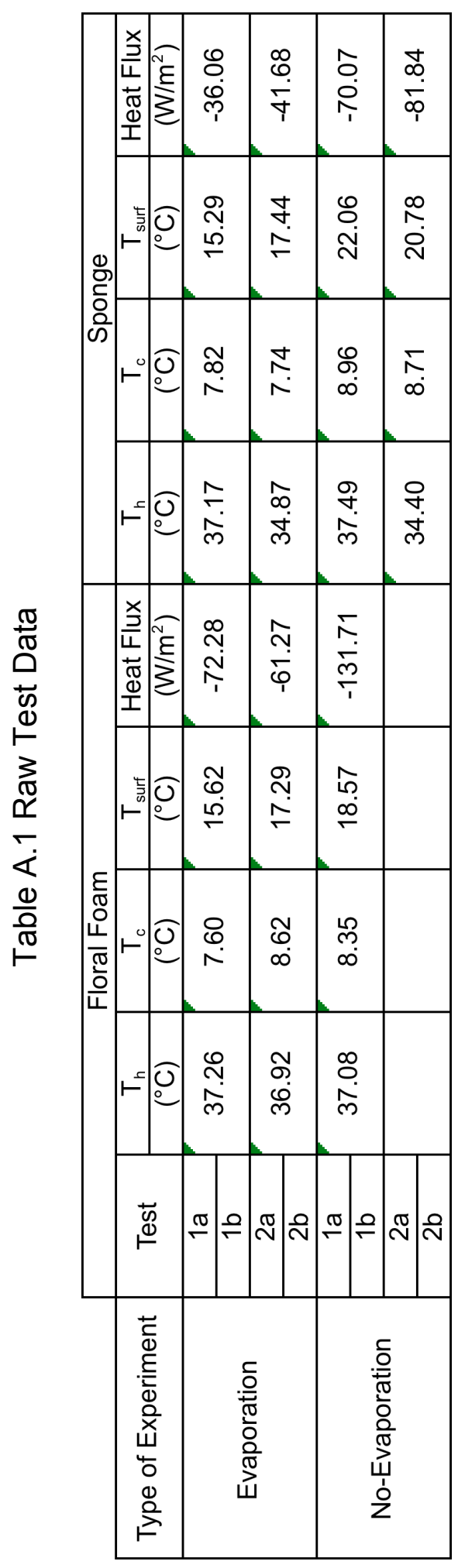




\section{APPENDIX B: Statistical Results}

For the heat flux results from the sponge and floral foam test, a 2 sample t-test and confidence intervals were done.

Results for the 2 samples t-test analysis of sponge:

Two-sample $\mathrm{T}$ for No-Evaporation Sponge Heat Flux vs Evaporation Sponge Heat Flux

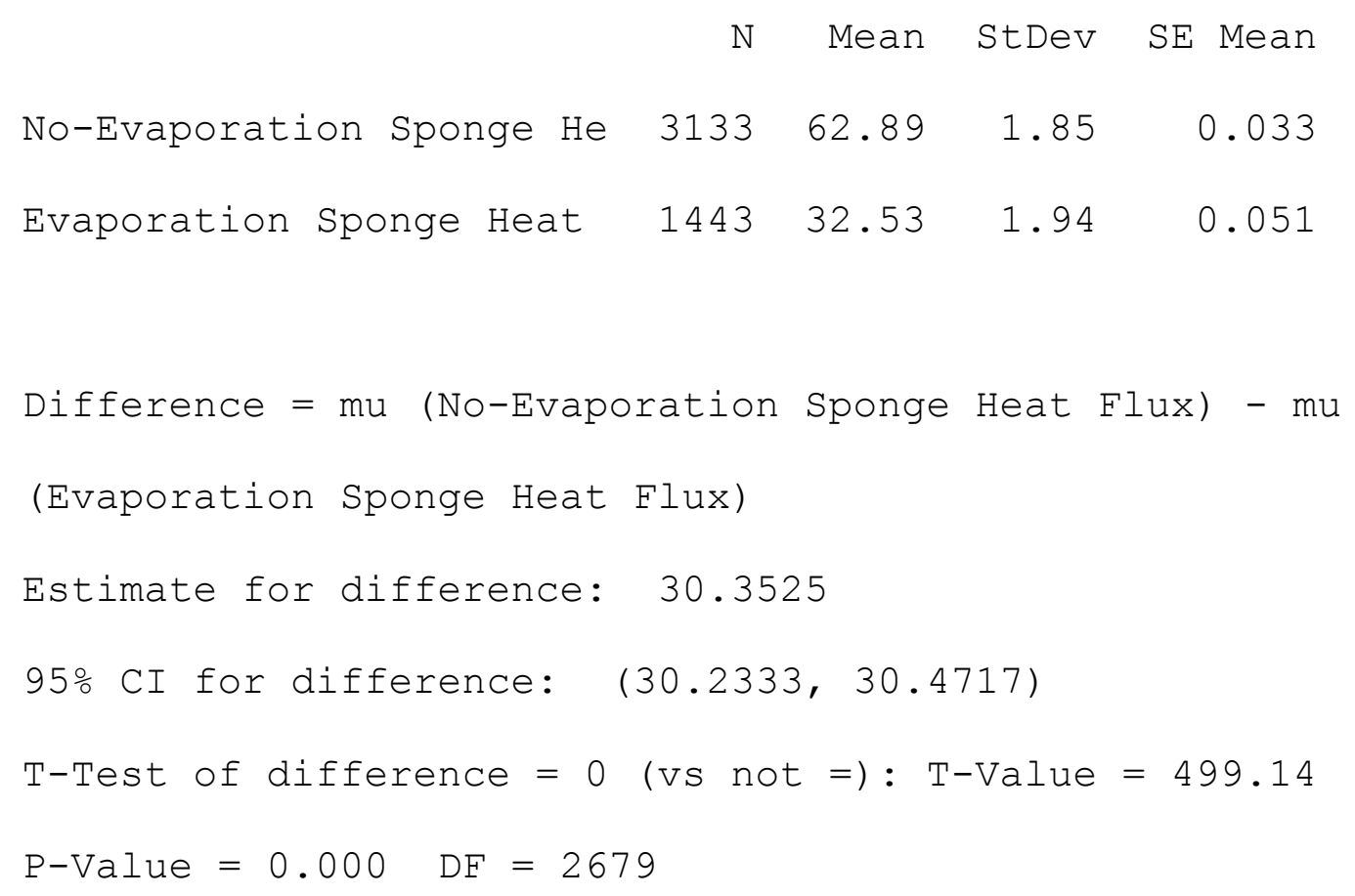


Results for the 2 samples t-test analysis of floral foam:

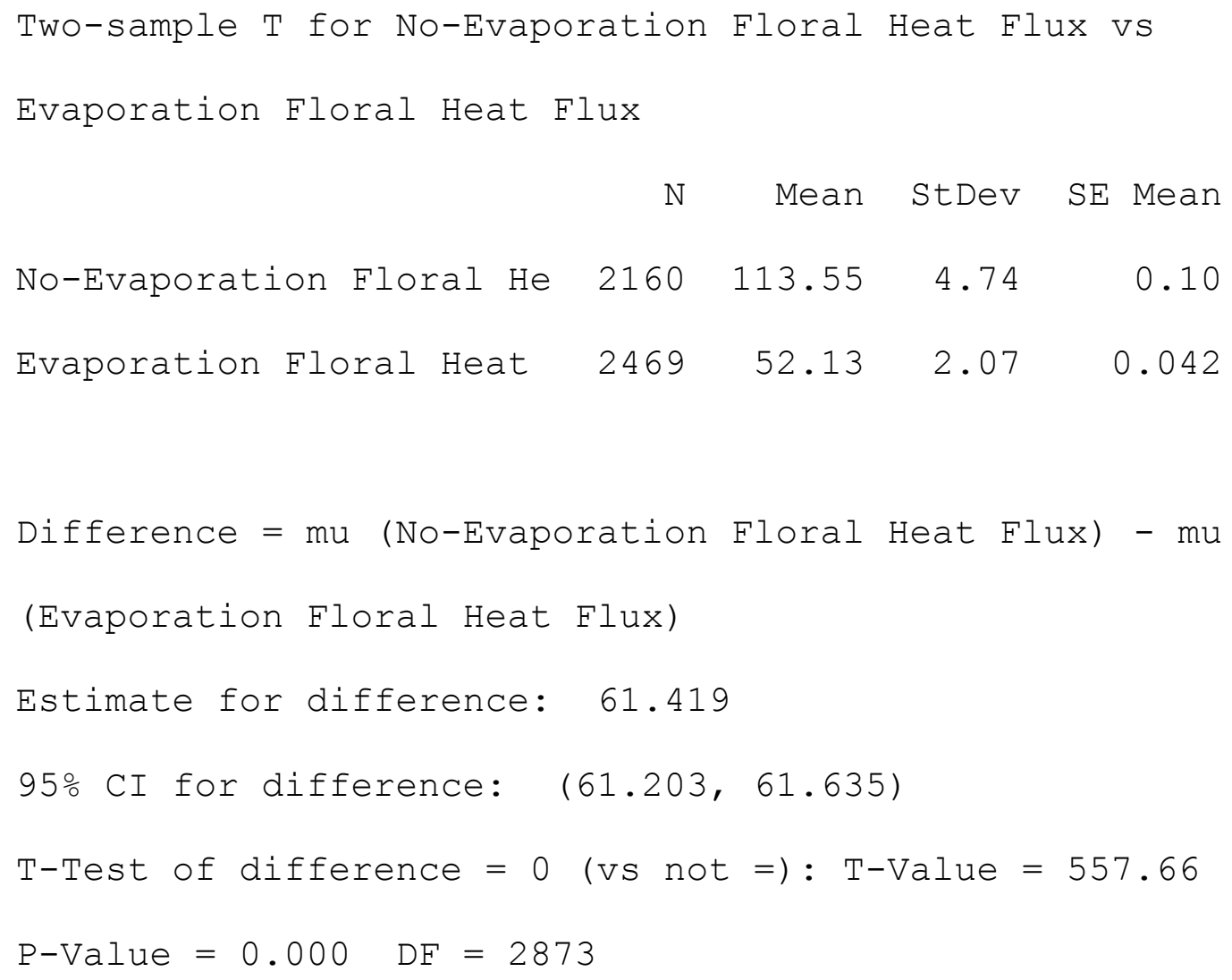

Results for the confidence intervals analysis on sponge:

- With no evaporation

$\begin{array}{lrrrrr}\text { Variable } & \mathrm{N} & \text { Mean } & \text { StDev } & \text { SE Mean } & \text { 95\% CI } \\ \text { No-Evaporation Sponge He } & 3133 & 62.89 & 1.85 & 1.79 & (59.39,66.39)\end{array}$

- With evaporation

$\begin{array}{lrrrrr}\text { Variable } & \mathrm{N} & \text { Mean } & \text { StDev } & \text { SE Mean } & \text { 95\% CI } \\ \text { Evaporation Sponge Heat } & 1443 & 32.53 & 1.94 & 2.63 & \text { (27.38, 37.69) }\end{array}$


Results for the confidence intervals analysis on floral foam:

- With no evaporation

$\begin{array}{lrrrrrr}\text { Variable } & \mathrm{N} & \text { Mean } & \text { StDev } & \text { SE Mean } & \text { 95\% CI } \\ \text { No-Evaporation Floral He } & 2160 & 113.55 & 4.74 & 2.15 & (109.33, & 117.77)\end{array}$

- With evaporation

$\begin{array}{lrrrrr}\text { Variable } & \mathrm{N} & \text { Mean } & \text { StDev } & \text { SE Mean } & \text { 95\% CI } \\ \text { Evaporation Floral Heat } & 2469 & 52.13 & 2.07 & 2.01 & (48.18,56.07)\end{array}$

